\title{
Melastomataceae no Parque Estadual da Pedra Branca, Rio de Janeiro, RJ, Brasil ${ }^{1}$
}

\author{
Marcus Felippe Oliveira da Silva ${ }^{2}$, Regina Helena Potsch Andreata ${ }^{3}$ e Paulo José Fernandes Guimarães ${ }^{4,5}$
}

Recebido: 16.01.2013; aceito: 12.07.2013

\begin{abstract}
Melastomataceae from Parque Estadual da Pedra Branca, Rio de Janeiro, Rio de Janeiro State, Brazil). Melastomataceae family comprises 67 genera and 1,321 species in Brazil, and it can be found in all Brazilian States. There are 28 genera and 338 species in Rio de Janeiro State. This study presents 26 species of Melastomataceae found on rain forests at the Parque Estadual da Pedra Branca at Rio de Janeiro municipality. Miconia is the richest genus with eight species (M. brasiliensis, M. calvescens, M. cinnamomifolia, M. latecrenata, M. mirabilis, M. prasina, M. staminea and M. tristis), followed by Tibouchina with five species (T. corymbosa, T. estrellensis, T. gaudichaudiana, T. granulosa and T. heteromalla), Leandra with four species (L. hirta, L. melastomoides, L. reversa and L. variabilis), Ossaea with three species (O. amygdaloides, $O$. confertiflora and $O$. marginata), Clidemia with two species (Clidemia capitellata and Clidemia hirta) and Meriania, Mouriri, Pleiochiton and Rhynchanthera (M. glabra, M. arborea, P. blepharodes and R. dichotoma) with one species each. Identification keys, descriptions, geographic distribution data, comments and illustrations are presented. Key words: Atlantic forest, biodiversity, Myrtales, taxonomy
\end{abstract}

RESUMO - (Melastomataceae no Parque Estadual da Pedra Branca, Rio de Janeiro, RJ, Brasil). Melastomataceae é representada no Brasil por 67 gêneros e 1.321 espécies, sendo encontrada em todos os Estados brasileiros. No Estado do Rio de Janeiro são registrados 28 gêneros e 338 espécies. Neste estudo foram tratadas as 26 espécies da família encontradas na Floresta Ombrófila Densa do Parque Estadual da Pedra Branca, localizado no município do Rio de Janeiro, RJ. Miconia é o gênero mais representativo com oito espécies (M. brasiliensis, M. calvescens, M. cinnamomifolia, M. latecrenata, M. mirabilis, M. prasina, M. staminea e M. tristis), seguido por Tibouchina com cinco espécies (T. corymbosa, T. estrellensis, T. gaudichaudiana, T. granulosa e T. heteromalla), Leandra com quatro espécies (L. hirta, L. melastomoides, L. reversa e $L$. variabilis), Ossaea com três espécies ( $O$. amygdaloides, $O$. confertiflora e $O$. marginata), Clidemia com duas espécies (Clidemia capitellata e Clidemia hirta) e Meriania, Mouriri, Pleiochiton e Rhynchanthera (Meriania glabra, Mouriri arborea, P. blepharodes e $R$. dichotoma) com uma espécie cada. São fornecidos chave para identificação, descrições, comentários, dados sobre a distribuição geográfica e ilustrações.

Palavras-chave: biodiversidade, Floresta Atlântica, Myrtales, taxonomia

\section{Introdução}

Melastomataceae está representada por cerca de 150 gêneros e 4.570 espécies (Clausing \& Renner 2001), distribuídas predominantemente nas regiões tropicais do globo (Wurdack 1962). No Brasil é a sexta maior família de Angiospermas (Baumgratz et al. 2006), com 67 gêneros e 1.321 espécies, sendo Miconia Ruiz et Pav., Leandra Raddi e Tibouchina
Aubl., os gêneros com maior representatividade (Baumgratz et al. 2012).

A família distribui-se por todos os Estados brasileiros, e em praticamente todos os domínios fitogeográficos, exceto na Caatinga senso estrito e no Pantanal (Baumgratz et al. 2006, Baumgratz et al. 2012, Goldenberg et al. 2012). No Estado do Rio de Janeiro a família Melastomataceae engloba 28 gêneros e 338 espécies (Baumgratz et al. 2012),

1. Parte da Dissertação de Mestrado do primeiro Autor

2. Programa de Pós-Graduação em Ciências Biológicas, Museu Nacional, Universidade Federal do Rio de Janeiro, Quinta da Boa Vista, São Cristóvão, 20940-040 Rio de Janeiro, RJ, Brasil

3. Universidade Santa Úrsula, Laboratório de Angiospermas, Rua Fernando Ferrari 75, 22231-040 Rio de Janeiro, RJ, Brasil

4. Instituto de Pesquisas Jardim Botânico do Rio de Janeiro, DIPEQ, Rua Pacheco Leão 915, 22460-030 Rio de Janeiro, RJ, Brasil

5. Autor para correspondência: paulojose.guimaraes@gmail.com 
sendo encontradas desde as restingas até as florestas pluviais alto montanas e os campos de altitude (Baumgratz et al. 2006, 2007, 2012, Barberena et al. 2008). Estudos florísticos recentes com a família foram realizados no Estado do Rio de Janeiro (Silva \& Baumgratz 2008, Silva 2011), inclusive em Unidades de Conservação (UC's) (Baumgratz et al. 2006, 2007, Barberena et al. 2008, Baumgratz \& Souza 2011).

Atualmente, apenas uma pequena parte da Floresta Atlântica no Estado do Rio de Janeiro está protegida em UC's (Fundação SOS Mata Atlântica/ INPE 2002), e dentre essas, destaca-se o Parque Estadual da Pedra Branca, localizado no centro do município do Rio de Janeiro e que guarda uma extensa área de Floresta Ombrófila Densa, porém em uma área sujeita à expansão urbana e ainda pouco conhecida pela ciência. Não existem muitas informações disponíveis sobre a área, mas alguns trabalhos podem ser destacados como os de Firme et al. (2001), sobre estrutura da vegetação; Oliveira et al. (2003), sobre biomassa de raízes finas e serapilheira; e o de Oliveira (2005), que trata sobre a história ambiental do Parque.

Este trabalho teve com objetivo inventariar as Melastomataceae no Parque Estadual da Pedra Branca e fornecer subsídios para iniciativas de conservação, além de atualizar o conhecimento taxonômico acerca da família na flora fluminense. São apresentados chave para identificação das espécies, descrições, ilustrações, dados sobre distribuição geográfica e particularidades dos táxons.

\section{Material e métodos}

O Parque Estadual da Pedra Branca (PEPB) localiza-se no centro geográfico do município do Rio de Janeiro $(\mathrm{RJ})$ e possui área de 12.500 ha (Semads 2001), ocupando cerca de $70 \%$ do Maciço da Pedra Branca (Costa 2002).

A vegetação ocorrente no PEPB é de Floresta Ombrófila Densa, sendo reconhecidas as formações submontana e montana. Em algumas localidades do PEPB houve extração de madeira, agricultura de subsistência e fabricação de carvão (Corrêa 1936), atividades responsáveis pela fragmentação da paisagem e formação de diversas florestas secundárias em diferentes estágios de regeneração (Oliveira 2005).

O levantamento das espécies foi feito em literatura e nos herbários FCAB, GUA, HB, P, R e RB, acrônimos segundo Thiers (2012). Expedições científicas mensais foram realizadas entre maio de 2006 e fevereiro de 2007, na área do Parque e no seu entorno, para coleta de espécimes e obtenção de dados sobre o habitat e outras particularidades, sendo o material herborizado segundo as técnicas usuais e depositado nos herbários R e RB.

A classificação de Melastomataceae adotada neste trabalho reconhece Memecyloideae como subfamília de Melastomataceae (Conti et al. 1996, APG III 2009, Goldenberg et al. 2012).

Quando necessário, devido à escassez de material para as descrições, foram analisadas exsicatas provenientes de outras localidades e que foram citadas como material adicional examinado. Estruturas importantes para uma única espécie ou gênero (como pseudoestípulas interpeciolares em Miconia cinnamomifolia) não foram citadas em todas as descrições, do mesmo modo outras características peculiares estão presentes apenas nos comentários da espécie. Algumas espécies carecem de comentários ambientais por não terem sido coletadas para este trabalho, e sendo seus registros no PEPB provenientes de vouchers depositados nos herbários visitados.

Táxons infraespecíficos não foram aceitos neste trabalho. Adotaram-se os conceitos de Radford et al. (1974) e Hickey \& King (2000) para as descrições. A classificação das formações vegetacionais segue Veloso et al. (1991). Dados sobre a distribuição geográfica foram obtidos na literatura especializada, especialmente em Baumgratz et al. (2012) e nas etiquetas de coleta das coleções examinadas.

\section{Resultados e Discussão}

No PEPB, Melastomataceae apresenta nove gêneros e 26 espécies, sendo Miconia Ruiz et Pav o gênero mais rico em espécies com oito, seguido por Tibouchina Aubl. (cinco), Leandra Raddi. (quatro), Ossaea DC (três), Clidemia D. Don (duas) e Meriania Sw., Mouriri Aubl., Pleiochiton Naudin ex A.Gray e Rhynchanthera DC., com uma espécie cada.

Dentre as espécies de Melastomataceae no PEPB, algumas apresentam ampla distribuição geográfica, como Clidemia hirta (L.) D. Don, Miconia calvescens DC., Miconia mirabilis (Aubl.) L.O. Willians e Miconia prasina (Sw.) DC. Por outro lado, são endêmicas do Estado do Rio de Janeiro, Leandra hirta Raddi, Meriania glabra (DC.) Triana, Tibouchina corymbosa (Raddi) Cogn., T. gaudichaudiana (DC.) Baill. e T. granulosa (Desr.) Cogn.

\section{Melastomataceae}

Arbustos, subarbustos, arvoretas ou árvores, eretas, prostradas, escandentes ou epífitas. Ramos 
cilíndrico a tetragonais, às vezes alados, sulcados ou achatados. Folhas isófilas, subisófilas ou anisófilas, decussadas, pecioladas; lâmina com indumento variado em ambas as faces, nervuras acródromas ou broquidódromas (Mouriri). Inflorescências de tipos variados, terminais e/ou axilares. Flores períginas ou epíginas, 4-6 meras, diclamídeas, dialipétalas, monoclinas. Cálice com um ou dois verticilos, caduco ou persistente no fruto. Corola com pétalas roxas, lilases, róseas, brancas ou amareladas, de formatos variados. Estames em número duplo ao de pétalas ou raramente em mesmo número e alternados com estaminódios, isomorfos a dimorfos, anteras com formatos variados, ápices rostrados, truncados, atenuados ou arredondados, geralmente 1-porosas, ou raramente deiscentes por duas fendas, conectivos prolongados ou não abaixo dos lóculos das anteras, raramente com glândula ventral (Mouriri), apêndices variados, ventrais e/ou dorsais. Ovário 2-5 locular, placentação axilar, livre a aderido ao hipanto, ápice com diversos tipos de tricomas ou glabro, estilete único, filiforme, estigma punctiforme, truncado ou capitado. Frutos secos ou carnosos, polispérmicos ou oligospérmicos, sementes de várias formas.

Chave para identificação das espécies de Melastomataceae do Parque Estadual da Pedra Branca

1. Lâminas foliares com nervação broquidódroma; conectivos providos de uma glândula dorsal

16. Mouriri arborea

1. Lâminas foliares com nervação acródroma; conectivos desprovidos de glândula dorsal

2. Estames de apenas um dos verticilos férteis, anteras com ápice rostrado ..... 21. Rhynchanthera dichotoma

2. Estames dos dois verticilos férteis, anteras com ápice atenuado ou truncado

3. Fruto do tipo cápsula

4. Conectivos com apêndices dorsais ascendentes, pétalas brancas, glabras

7. Meriania glabra

4. Conectivos sem apêndices dorsais ascendentes; pétalas roxas, ciliadas

5. Árvores, face abaxial da lâmina foliar com tricomas dendríticos; filetes dos estames revestidos por tricomas simples

6. Face adaxial da lâmina foliar bulada, recoberta por tricomas com a base pluriramificada, face abaxial foveolada 23. Tibouchina estrellensis

6. Ambas as faces da lâmina foliar planas; face adaxial recoberta por tricomas com a base bi ou triramificada, face abaxial não foveolada 25. Tibouchina granulosa

5. Arbustos, face abaxial da lâmina foliar sem tricomas dendríticos; filetes dos estames revestidos por tricomas glandulares pedicelados

7. Face adaxial da lâmina foliar com indumento híspido, base truncada com as nervuras laterais externas divergindo acima das demais 22. Tibouchina corymbosa

7. Face adaxial da lâmina foliar com indumento seríceo e/ou estrigoso, base cordada ou obtusa, com as nervuras laterais externas divergindo junto com as internas

8. Lâmina foliar 9-12 cm compr., face adaxial da lâmina foliar bulada, estrigososerícea; face abaxial foveolada, vilosa e seríceo-estrigosa; conectivos glandulares

26. Tibouchina heteromalla

8. Lâmina foliar 3-9 cm compr., ambas as faces da lâmina foliar planas, face adaxial adpresso-serícea, face abaxial tomentoso-serícea; conectivos glabros

24. Tibouchina gaudichaudiana

3. Fruto do tipo baga

9. Arbustos epifíticos ou escandentes

20. Pleiochiton blepharodes

9. Árvores ou arbustos terrestres nunca escandentes

10. Inflorescências somente terminais ou terminais e laterais

11. Pétalas com ápice obtuso ou arredondado

12. Face abaxial das lâminas foliares glabras ou raramente subglabras, neste caso, tricomas exclusivamente sobre as nervuras

13. Pseudoestípulas interpeciolares presentes; folhas e ramos jovens esparsamente cobertos por indumento estrelado-furfuráceo; inflorescências somente terminais 10. Miconia cinnamomifolia 
13. Pseudoestípulas interpeciolares ausentes; folhas e ramos jovens glabros; inflorescências terminais e laterais 15. Miconia tristis

12. Face abaxial das lâminas foliares sempre recoberta por indumento persistente inclusive entre as nervuras, ainda que apenas esparsamente

14. Lâminas foliares com ao menos um par de nervuras suprabasais
15. Folhas com base agudo-atenuada, brácteas persistentes no fruto

13. Miconia prasina

15. Folhas com base subcordada, cordada, obtusa ou arredondada, brácteas não persistentes no fruto

16. Pétalas ca. 1,8 mm compr., glabras ou esparsamente pilosas, anteras 7,5-8,5 $\mathrm{mm}$ compr., linear-subuladas 14. Miconia staminea

16. Pétalas ca. $8 \mathrm{~mm}$ compr., papilosas, anteras ca. $3 \mathrm{~mm}$ compr., oblongas

9. Miconia calvescens

14. Lâminas foliares com todos os pares de nervuras basais

17. Lâmina foliar com a face abaxial esparsamente estrelado furfurácea; anteras com poro ventral amplo, às vezes, semelhante a uma rima

11. Miconia latecrenata

17. Lâmina foliar com a face abaxial densamente estrelado-furfurácea; anteras com poro apical diminuto

18. Lâmina foliar com 5-7 nervuras; anteras linear-subuladas, 7-8 mm compr., com ápice atenuado 12. Miconia mirabilis

18. Lâmina foliar com 3 nervuras; anteras oblongas, ca. 2,7 mm compr., com ápice truncado 8. Miconia brasiliensis

11. Pétalas com ápice agudo ou acuminado

19. Ramos, pecíolos e eixos da inflorescência com tricomas dendríticos

6. Leandra variabilis

19. Ramos, pecíolos e eixos da inflorescência com tricomas simples

20. Face adaxial da lâmina foliar setosa, nervuras acródromas basais; inflorescências maduras com ramos escorpióides; brácteas não involucrais, ca. 2 compr 5. Leandra reversa

20. Face adaxial da lâmina foliar pilosa, serícea ou adpresso-híspida, nervuras acródromas suprabasais; inflorescências maduras sem ramos escorpióides; brácteas involucrais, 6-7 $\mathrm{mm}$ compr.

21. Face adaxial da lâmina foliar bulada, adpresso-híspida, face abaxial foveolada, híspido-escabra; brácteas externamente estrigosas; flores 6-meras; ovário 4-locular 4. Leandra melastomoides

21. Ambas as faces da lâmina foliar planas, pilosas e seríceas sobre as nervuras, glabrescentes; brácteas externamente seríceas ou às vezes seríceo-glandulosas; flores 5-meras; ovário 3-locular 3. Leandra hirta

10. Inflorescências axilares ou em porções áfilas dos ramos, nunca terminais

22. Inflorescências somente axilares; pétalas com ápice obtuso ou arredondado

23.Indumento dos ramos, pecíolos e eixos da inflorescência pilosos e vilosos, com tricomas simples, dendríticos, aracnóides e setoso-glandulares; lacínias internas do cálice desenvolvidas, 0,5-1,6 mm compr., zona do disco do hipanto glabra; conectivos dos estames não prolongados e nem calcarados .... 1. Clidemia capitellata

23.Indumento dos ramos, pecíolos e eixos da inflorescência setoso e setuloso, com tricomas simples e estrelado-furfuráceos (nunca dendríticos); lacínias internas do cálice reduzidas a um anel membranáceo, zona do disco do hipanto com escamas fimbriadas; conectivos dos estames pouco prolongados, calcarados dorsalmente 
22. Inflorescências axilares ou em nós áfilos dos ramos; pétalas com ápice agudo a acuminado

24. Ramos e pecíolos glabrescentes; margem da lâmina foliar totalmente recoberta por tricomas adpresso-setosos 19. Ossaea marginata

24. Ramos e pecíolos com indumento persistente; margem da lâmina foliar somente ciliada

25. Lâmina foliar com a margem nitidamente crenulada, face adaxial densamente vilosa 18. Ossaea confertiflora

25. Lâmina foliar com a margem inconspicuamente crenulada ou inteira, face adaxial esparsa a moderadamente vilosa 17. Ossaea amygdaloides

\section{Clidemia capitellata (Bonpl.) D. Don, Mem Wern.} Nat. Hist. Soc. 4(2): 310. 1823.

Subarbusto ca. $1 \mathrm{~m}$ alt. Indumento dos ramos, pecíolos e eixos das inflorescências piloso e viloso, com tricomas simples, dendríticos, aracnoides e setoso-glandulares. Folhas com pecíolos $0,8-2,2 \mathrm{~cm}$ compr.; lâmina 6,8-11,5 × 2,4-4,6 cm, oval-elíptica, base obtusa a cordada, ápice agudo-acuminado ou falcado, margem crenulada, ciliada, face adaxial plana densamente estrigosa, com tricomas aracnoides, dendríticos e setoso-glandulares esparsos, face abaxial pouco foveolada, moderadamente pilosa e vilosa apenas sobre as nervuras e com tricomas aracnóides e dendríticos esparsos na superfície, 5-7 nervuras acródromas suprabasais, com as internas ca. $2 \mathrm{~mm}$ acima da base. Inflorescências espiciformes laterais ou terminais até $6 \mathrm{~cm}$ compr.; brácteas e profilos não involucrais, 0,4-2,5 mm compr., lanceolados, pilosos. Flores 5-meras, hipanto 3-3,5 mm compr., tubuloso, piloso e viloso com tricomas simples, dendríticos e aracnoides, zona do disco glabra; lacínias do cálice, externas 3-3,5 mm compr., subuladas, internas 0,5-1,6 mm compr., arredondadas, soldadas às externas, pétalas 5-6 mm compr., brancas, obovadas, ápice obtuso, glabras. Estames 10, isomorfos, com filetes 2,8-3,2 mm compr., glabros, anteras 3-3,5 mm compr., oblongas, conectivos não prolongados e inapendiculados. Ovário 4-locular, adnato ao hipanto na base, setoso-glanduloso e estrelado. Baga roxonigrescente.

Material examinado: BRASIL. RIO DE JANEIRO: Rio de Janeiro, Parque Estadual da Pedra Branca, estrada da Boiúna, próximo ao Lar de Frei Luís, 16-VI-2006, fl., fr., M.F.O. Silva 97 (R, RB); Boiúna, trilha que leva aos fundos do Clube da Polícia Civil, 16-VI-2006, fl., M.F.O. Silva 99 (R, RB); estrada do Rio Grande, próximo à Pedra Branca, 24-X-1945, fr., L. Emgydio \& P. Dansereau 360 (R); Pedra Branca: 22-VIII-1932, fr., A.C. Brade 11971 (R).

Ocorre desde o México até o Brasil (Goldenberg et al.2005), tendo sido coletada em praticamente todos os Estados brasileiros, com exceção do Piauí, Espírito Santo e Rio Grande do Sul (Michelangeli \& Reginato 2012). Pode ser reconhecida no PEPB pelo indumento dos ramos, pecíolos e eixos da inflorescência piloso e viloso, com tricomas simples, dendríticos, aracnóides e setoso-glandulares, inflorescências laterais espiciformes, estames inapendiculados e tricomas glandulosos no ápice do ovário. Para maiores informações sobre Clidemia capitellata e suas espécies afins ver Goldenberg et al. (2005).

No PEPB foi coletada apenas nas margens de uma trilha na Boiúna, em uma área sujeita à expansão urbana, formando uma pequena população. Os indivíduos dessa espécie ocorrem em barrancos sombreados e úmidos.

2. Clidemia hirta (L.) D. Don, Mem. Wern. Nat. Hist. Soc. 4(2): 309. 1823.

Arbusto 0,5-1,5 m alt. Indumento dos ramos, pecíolos e eixos da inflorescência setoso e setuloso com tricomas simples e estrelado-furfuráceos. Folhas com pecíolos $0,5-1,8 \mathrm{~cm}$ compr.; lâmina $3,7-10,1 \times 1,9-5,8 \mathrm{~cm}$, oval a ovado-elíptica, base subcordada, arredondada ou assimétrica ápice agudoacuminado, margem crenulada, face adaxial bulada setosa com tricomas simples, face abaxial foveolada, face abaxial esparsa a moderadamente setosa a setulosa, com tricomas simples e estrelado-furfuráceos, 5-7(-9) nervuras acródromas suprabasais, com as internas 1,5-2 $\mathrm{mm}$ acima da base. Inflorescências metabotrióides, botrióides ou tirsóides axilares, $5-8 \mathrm{~cm}$ compr.; brácteas e profilos não involucrais, 1-1,8 mm compr., linear-lanceolados, setoso-ciliados. Flores 5-meras, hipanto 3-3,5 mm compr., campanulado, setoso e setuloso, com tricomas simples e estreladofurfuráceos, zona do disco com escamas fimbriadas; lacínias do cálice, externas ca. 2,5 mm compr., subuladas, internas reduzidas a um anel membranáceo; pétalas 5-8 mm compr., brancas, obovadas, ápice arredondado, glabras. Estames 10, isomorfos, com filetes 1,5-1,8 mm compr., glabros, anteras 3,8-4 mm 
compr., subuladas, conectivos pouco prolongados, dorsalmente bilobados. Ovário 5-locular, adnato ao hipanto na base, glabro. Baga roxo-nigrescente.

Material examinado: BRASIL. Rio DE JANeIRo: Rio de Janeiro, Parque Estadual da Pedra Branca, Boiúna, atrás do Clube da Polícia Civil, 24-VI-2006, fl., fr., M.F.O. Silva 105 (R, RB); caminho que leva à represa do Camorim, 25-VIII-1980, fl., M.C. Vianna et al. 1518 (GUA); caminho que leva à represa do Camorim, 25-VIII-1980, fl., fr., A.S. Leão 157 (GUA).

Ocorre desde o México até o Sul do Brasil (Goldenberg et al. 2005), sendo que em território brasileiro pode ser encontrada em quase todos os Estados, com exceção de Piauí, Rio Grande do Norte e Tocantins (Michelangeli \& Reginato 2012). É a única espécie de Melastomataceae no PEPB que apresenta escamas fimbriadas na zona do disco, estames com conectivos dorsalmente bilobados e as lacínias internas do cálice reduzidas a um anel membranáceo.

Foi registrada por todo o Parque, principalmente em áreas abertas e na margem de trilhas, onde foram observadas populações com maior número de indivíduos.

3. Leandra hirta Raddi, Mem. Mat. Fis. Soc. Ital. Sci. 18 (2): 387.1820.

Figura 1 e-g

Arbusto, 1-1,5 m alt. Indumento dos ramos, pecíolos e eixos da inflorescência hirtelo-piloso com tricomas simples e adpressos, glabrescentes. Folhas com pecíolos 0,5-2,2 cm compr., lâmina 3,5-11 $\times$ 2,3-5,8 cm, elíptica, base agudo-acuminada ou assimétrica, ápice acuminado, margem crenulada no terço superior, inteira na base, ciliada, face adaxial plana hirtelo-pilosa, glabrescente com tricomas simples, face abaxial plana, esparsamente hirtelopilosa, glabrescente com tricomas simples, 5-7 nervuras acródromas suprabasais, com as internas ca. $1,5 \mathrm{~cm}$ acima da base. Inflorescências em tirsóides, sem ramos escorpióides na maturidade, terminais, $4-8 \mathrm{~cm}$ compr.; brácteas e profilos não involucrais 4-6 mm compr., lanceolado-agudos, pilosos ou esparsamente piloso-glandulosos. Flores 5-meras, hipanto ca. $4 \mathrm{~mm}$ compr., tubuloso, hirtelo-piloso, com tricomas simples ou raramente pedicelado- glandulosos, zona do disco glabra; lacínias do cálice, externas ca. 1,5 mm compr., triangulares, internas $0,8-1,3 \mathrm{~mm}$ compr., subuladas; pétalas ca. $3 \mathrm{~mm}$ compr., brancas, linear-subuladas, ápice agudo, glabras. Estames 10, subisomorfos com filetes ca. $4 \mathrm{~mm}$ compr., glabros, anteras ca. $5 \mathrm{~mm}$ compr., oblongas, conectivos não prolongados inapendiculados ou inconspicuamente bilobados. Ovário 3-locular, adnato ao hipanto até o terço superior, ápice setoso. Baga roxo-nigrescente.

Material examinado: BRASIL. Rio DE JANEIRO: Rio de Janeiro, Parque Estadual da Pedra Branca, trilha para a represa do Camorim, 11-VIII-2006, fl., M.F.O. Silva 110 (R, RB, GUA); Pau-da-fome, trilha do aqueduto, 7-X-2006, fr, M.F.O. Silva 131 (R, RB); Camorim, 19-XII-1933, fl., s.c., s.n (R114945); Pedra Bonita, 30-I-1933, veg., A.C. Brade 12426 (R).

Endêmica do Estado do Rio de Janeiro (Souza \& Baumgratz 2012a). Pode ser reconhecida no PEPB pelos tricomas esbranquiçados por toda a planta, pelas brácteas caducas e não congestas e pelos estames amarelos.

Alguns espécimes coletados no PEPB apresentam uma quantidade quase imperceptível de tricomas glandulares, distribuídos apenas nas brácteas e hipanto, que na maioria das vezes caducam após a herborização e, portanto observados apenas em material fresco. A presença de tricomas glandulares é tida como diagnóstica em Leandra bergiana Cogn., espécie que habita toda a região Sudeste do Brasil e os Estados do Paraná e Santa Catarina (Souza \& Baumgratz 2012a). Apesar de serem espécies afins, L. hirta não tem sido descrita apresentando tricomas glandulares. (Souza \& Baumgratz 2009, Souza \& Baumgratz 2011). Contudo, após a conferência dos exemplares-tipo e históricos dessas duas espécies depositados no Herbário de Paris, percebeu-se maior correspondência morfológica dos indivíduos coletados no PEPB com Leandra hirta Raddi, que tem como localidade-tipo o Corcovado, também localizado no município do Rio de Janeiro (Marcelo Reginato, dados não publicados).

No PEPB habita áreas abertas, margens de trilhas e outros locais com vegetação secundária.

4. Leandra melastomoides Raddi, Mem. Soc. Hist. Ital. Fis. 18: 386. 1820.

Figura $1 \mathrm{~h}-\mathrm{j}$

Arbusto, 0,5-1,5 $\mathrm{m}$ alt. Indumento nos ramos, pecíolos e eixos da inflorescência híspido-escabro com tricomas simples. Folhas com pecíolos 0,5-2 cm compr.; lâmina 5-11,5 × 2-3,7 cm, elíptica, base atenuada, ápice agudo, margem crenulada, ciliada, face adaxial bulada, adpresso-híspida com tricomas 


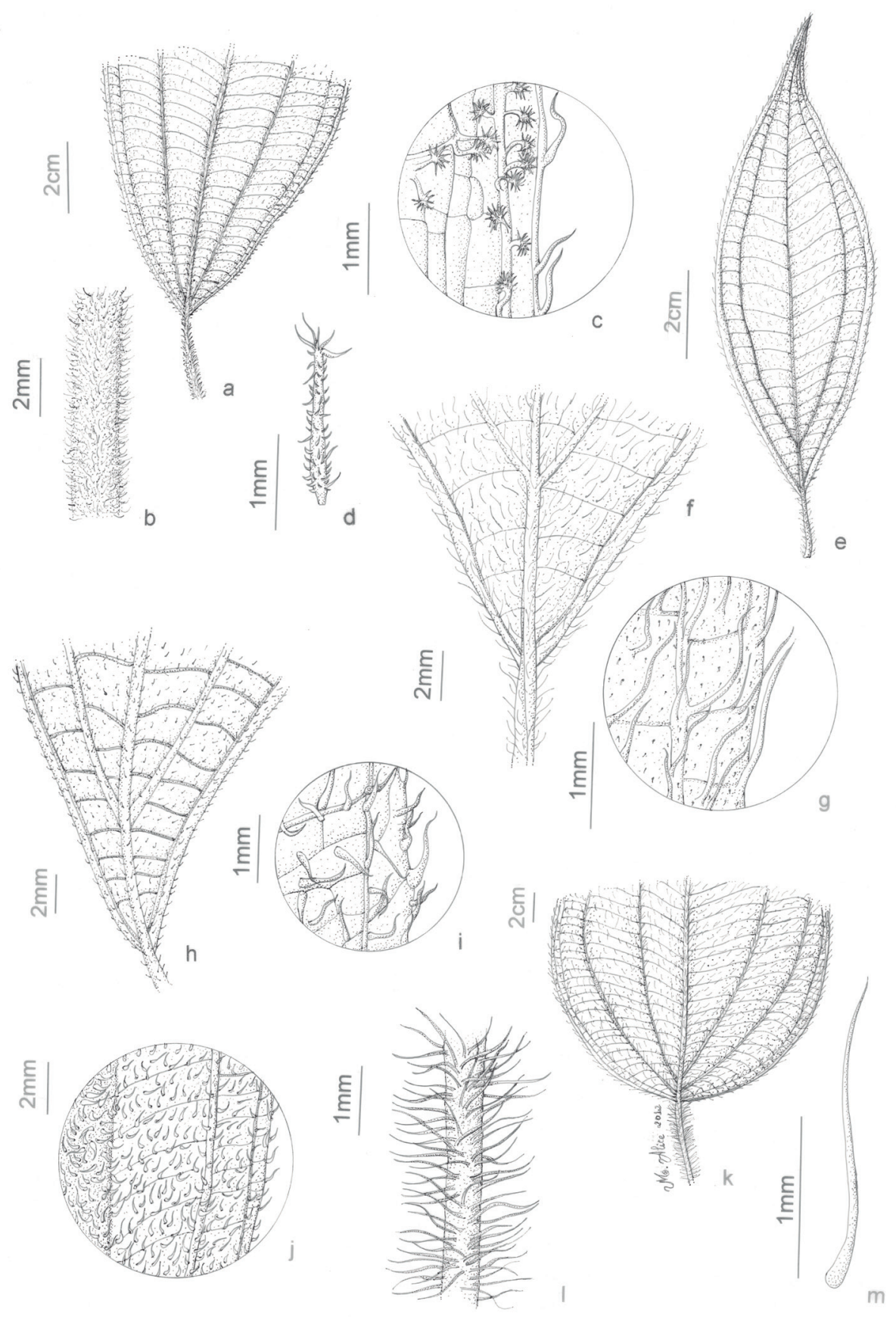

Figura 1. Espécies de Leandra do P.E. da Pedra Branca, Rio de Janeiro. a-d. Leandra variabilis. a. Base da lâmina foliar. b. Ramo. c. Detalhe do indumento na margem e na face abaxial da lâmina foliar. d. Detalhe do tricoma dendrítico dos ramos. e-g. Leandra hirta. e. Lâmina foliar. f. Detalhe da base da lâmina. g. Detalhe do indumento na margem e na face abaxial da lâmina foliar. h-j. Leandra melastomoides. h. Base da lâmina foliar. i. Detalhe do indumento na margem e na face abaxial da lâmina foliar. j. Detalhe do indumento na margem e na face adaxial da lâmina foliar. k-m. Leandra reversa. k. Base da lâmina foliar. 1. Ramo. m. Detalhe do tricoma setoso dos ramos. (a-d: J.F.A. Baumgratz 983; e-g: R.C. Forzza 2825; h-j: R. Valka Alves 4363; k-m: A.M. Amorim 7601).

Figure 1. Leandra species of P.E. da Pedra Branca, Rio de Janeiro. a-d. Leandra variabilis. a.Leaf base. b. Branch. c. Detail of indumentum covering margins and abaxial leaf surface. d. Detail of dendritic hairs. e-g. Leandra hirta. e. Leaf blade. f. Detail of leaf base. g. Detail of indumentum covering margins and abaxial leaf surface. h-j. Leandra melastomoides. h. Detail of leaf base. i. Detail of indumentum covering margins and abaxial leaf surface. j. Detail of indumentum covering margins and adaxial leaf surface. k-m. Leandra reversa. k. Leaf base. 1. Branch. m. Detail of setose hair. (a-d: J.F.A. Baumgratz 983; e-g: R.C. Forzza 2825; h-j: R. Valka Alves 4363; k-m: A.M. Amorim 7601). 
simples, face abaxial bulada, adpresso-híspida, com tricomas simples, 5-7 nervuras acródromas suprabasais, as internas até $6 \mathrm{~mm}$ acima da base. Inflorescências em tirsóides de glomérulos, sem ramos escorpióides na maturidade, terminais, $5-7 \mathrm{~cm}$ compr.; brácteas e profilos involucrais ca. $4 \mathrm{~mm}$ compr. lanceoladas, moderada a densamente estrigosas na face externa. Flores 6-meras, hipanto 3,5-4 mm compr., tubuloso, estrigoso com tricomas simples, zona do disco glabra; lacínias do cálice, externas ca. 1,5 mm compr., obtusas, internas 1-1,2 mm compr., linear-subuladas; pétalas ca. $3 \mathrm{~mm}$ compr., brancas linear-subuladas, ápice agudo, glabras. Estames 12, subisomorfos com filetes 2,4-2,8 mm compr., glabros, anteras 2,5-3 mm compr., oblongas, conectivos pouco prolongados e inapendiculados ou inconspicuamente bilobados. Ovário 4-locular, adnato ao hipanto até o terço superior, setoso. Baga roxo nigrescente.

Material examinado: BRASIL. RIO DE JANEIRO: Rio de Janeiro, Parque Estadual da Pedra Branca, Camorim, trilha para a represa, 11-VIII-2006, fl., fr., M.F.O. Silva 121 (RB); estrada da Boca do Mato, trilha para a represa do Camorim, 25-VIII-1980, fr., E.S.F. Rocha 160 (GUA); morro do Pau-da-fome, 2-X-1980, fl., C.M.S. Lira et al. 284 (GUA).

Endêmica do Brasil ocorre nos Estados da Paraíba, Bahia, Goiás, Distrito Federal, Minas Gerais, Espírito Santo, Rio de Janeiro, São Paulo, Paraná e Santa Catarina (Souza \& Baumgratz 2012a). No PEPB distingue-se das demais espécies pela presença de inflorescências glomeriformes, brácteas involucrais, flores hexâmeras e pétalas de ápice agudo. Para maiores informações ver Souza \& Baumgratz (2009) e Baumgratz \& Souza (2011). Ocorre no PEPB em margens de trilhas e áreas abertas.

5. Leandra reversa (DC.) Cogn. in Mart., Eichler \& Urban., Fl. bras. 14(4): 198.1886.

Figura 1 k-m

Arbusto, 1-1,5 m alt. Indumento dos ramos, pecíolos e eixos da inflorescência setoso com tricomas simples e glandulares pedicelados. Folhas com pecíolos 1,4-6,7 cm compr.; lâmina $(5,6-) 12-18,3 \times(3,4-) 6,2-10,5 \mathrm{~cm}$, ovada, base arredondada ápice agudo-acuminado, margem crenulada, ciliada, face adaxial plana, densamente setosa, com tricomas simples, face abaxial plana, moderadamente setoso-flexuosa com tricomas simples, 7-9 nervuras acródromas basais. Inflorescências em tirsóides escorpióides, terminais, ca. 12,5 cm compr.; brácteas e profilos não involucrais 1-2 mm compr., linear-lanceoladas, setoso-ciliadas. Flores 5-meras, hipanto ca. $2 \mathrm{~mm}$ compr., campanulado, setoso com tricomas simples e glandulares pedicelados, zona do disco glabra; lacínias do cálice, externas ca. $0,7 \mathrm{~mm}$ compr., triangulares, internas inconspícuas; pétalas 2-2,3 mm compr., brancas ou róseas, linearlanceoladas, ápice agudo, glabras. Estames 10, isomorfos, com filetes ca. $3 \mathrm{~mm}$ compr., glabros, anteras ca. $2 \mathrm{~mm}$ compr., oblongas, conectivos pouco ou não prolongados e inconspicuamente bilobados. Ovário 4-5 locular, adnato ao hipanto na base, setosoglanduloso. Baga roxo-nigrescente.

Material examinado: BRASIL. Rio DE JANEIRo: Rio de Janeiro, Parque Estadual da Pedra Branca, estrada do Camorim, próximo ao portão do Parque, 11-VIII-2006, fl., M.F.O. Silva, 122 (R, RB); núcleo do Pau-da-fome, ao lado da sede do Parque, 7-X-2006, fr., M.F.O. Silva, 132 (R, RB).

Distribui-se pela Bolívia, Peru e Brasil (Souza e Baumgratz 2009) e neste foi coletada nos Estados do Piauí, Minas Gerais, Espírito Santo, Rio de Janeiro, São Paulo, Paraná e Santa Catarina (Souza \& Baumgratz 2012a). Pode ser reconhecida no PEPB, graças ao indumento avermelhado que recobre a planta e pelas grandes folhas ovadas e membranáceas, possuindo até nove nervuras acródromas basais. É subordinada à Leandra seção Secundiflorae (Cogniaux 1886-1888), caracterizada pelas inflorescências com ramos tipicamente escorpióides. Porém, no início do desenvolvimento do eixo floral a inflorescência apresenta-se bastante congesta, o que dificulta a observação dos ramos escorpióides.

Leandra reversa está bem distribuída no PEPB em diversas altitudes, preferencialmente em locais mais úmidos e sombreados onde forma grandes populações.

6. Leandra variabilis Raddi, Melast. Bras.: 42, tab 5, fig 2. 1828.

Figura 1 a-d

Arbusto, $4 \mathrm{~m}$ alt. Indumento dos ramos, pecíolos e eixos da inflorescência viloso com tricomas dendríticos e ferrugíneos nos ramos mais novos, depois glabrescente. Folhas com pecíolos 1,8-3,3 cm compr.; lâmina 6,2-21,5 × 1,6-8,9 cm elíptica, base agudo-atenuada, ápice agudo, margem inconspicuamente crenulada, face adaxial plana, esparsa a moderadamente híspido-setosa, tricomas 
simples, face abaxial plana, moderadamente vilosa com tricomas dendríticos curtos, dendríticos longos e com projeções laterais curtas, 5-7 nervuras acródromas suprabasais, com as internas ca. $3 \mathrm{~mm}$ acima da base. Inflorescências em tirsóides sem ramos escorpioides na maturidade, terminais, 5,6-7,8 cm compr.; brácteas e profilos não involucrais, $0,8-1,5 \mathrm{~mm}$, lanceoladoagudos e viloso-dendríticos. Flores 5-meras, hipanto ca. $3 \mathrm{~mm}$ compr., tubuloso, densamente setoso com tricomas dendríticos curtos a longos e estrelados sésseis, zona do disco setosa; lacínias do cálice, externas ca. 1,4 mm compr., subuladas, internas ca. $1 \mathrm{~mm}$ compr., triangulares, parcialmente soldadas às externas; pétalas ca. 1,6 $\mathrm{mm}$ compr., brancas, linear-subuladas com ápice agudo, glabras. Estames 10, isomorfos, com filetes ca. $7 \mathrm{~mm}$ compr., glabros, anteras ca. $8 \mathrm{~mm}$ compr., oblongas, conectivos não prolongados e dorsalmente pouco espessados. Ovário 4-locular, adnato ao hipanto na base, setoso. Baga roxo-nigrescente.

Material examinado: BRASIL. RIO DE JANEIRO: Rio de Janeiro, Parque Estadual da Pedra Branca, Camorim, trilha para a represa, 11-VIII-2006, fr., M.F.O. Silva 125 (R, RB); margem da represa do Camorim, 11-VI-2006, fr., M.F.O. Silva 240 (R, RB); rio Camorim, 10-III-2007, fl., M.F.O. Silva 241 (GUA).

Leandra variabilis é endêmica do Brasil e ocorre nos Estados da Bahia, Espírito Santo, Rio de Janeiro, São Paulo, Paraná, Santa Catarina e Rio Grande do Sul (Souza \& Baumgratz 2012a). Os exemplares do PEPB foram inicialmente enquadrados em Leandra dasytricha (A. Gray) Cogn., espécie considerada atualmente como um sinônimo de $L$. variabilis (Reginato \& Goldenberg 2012). Pode ser identificada pelos tricomas ferrugíneos e dendríticos que recobrem os ramos, e pelas dimensões avantajadas de suas folhas.

Foi coletada sempre em locais úmidos e sombreados mais preservados, próximo às margens da represa e do rio.

7. Meriania glabra (DC.) Triana, Trans. Linn. Soc. Bot. 28(1): 66. 1871.

Árvore ca. $2 \mathrm{~m}$ alt. Indumento dos ramos, pecíolos e eixos da inflorescência muito esparso e cedo caduco, aparentemente glabro. Folhas com pecíolos 0,8-2 cm compr.; lâmina 7,2-16,5 × 4-7,5 cm, elíptica a ovalelíptica, base aguda, ápice acuminado ou falcado, margem inteira, face adaxial plana, glabra, face abaxial plana, glabra, 3 nervuras acródromas suprabasais, com as internas ca. $2 \mathrm{~mm}$ acima da base. Inflorescências em tríades, terminais, ca. $5 \mathrm{~cm}$ compr.; brácteas e profilos não vistos. Flores 5-meras, hipanto ca. $4 \mathrm{~mm}$ compr., campanulado, glabro, zona do disco glabra; lacínias do cálice unilobadas, ca. 2,5 mm irregulares; pétalas 15-18 mm compr., brancas, obovadas, ápice obtuso, glabras. Estames 10, dimorfos com filetes glabros e anteras subuladas, antessépalos com filetes 7-9 mm compr. e anteras 6-9 mm compr., antepétalos com filetes $8-10 \mathrm{~mm}$ compr. e anteras $4-5 \mathrm{~mm}$ compr., conectivos dorsalmente calcarados e com apêndices ascendentes bilobados ou ligulados. Ovário 5-locular, adnato ao hipanto até o terço superior, glabro. Cápsula castanha.

Material examinado: BRASIL. Rio DE JANEIRO: Rio de Janeiro, Parque Estadual da Pedra Branca, bacia de São Gonçalo do Amarante, Pindobal, 14-X-1993, fl., R. Ribeiro \& C.A.L. Oliveira s.n (GUA42357); pico da serra do Nogueira, 3-III-1989, fl., S.R. Sodré et al. 155 (GUA).

Meriania glabra é endêmica do Estado do Rio de Janeiro (Chiavegatto 2012) e ameaçada de extinção, segundo Chiavegatto \& Baumgratz (2008). No PEPB é diferenciada das demais Melastomataceae pela morfologia do estame com apêndice ascendente dorsal no conectivo, sendo a única espécie pertencente à tribo Merianieae.

Não foi possível recoletar essa espécie no PEPB, e informações relacionadas ao tipo de ambiente ocupado e outras particularidades necessitariam de observações adicionais.

8. Miconia brasiliensis (Spreng.) Triana, Trans. Linn. Soc. London 28: 118. 1871.

Figura $2 \mathrm{a}-\mathrm{b}$

Árvore 3-10 m alt. Indumento dos ramos, pecíolos e eixos da inflorescência moderada a densamente estrelado-furfuráceo com tricomas dendríticos, depois caducos. Folhas com pecíolos 0,5-1,4 cm compr.; lâmina 4-11,7 × 3-8,2 cm, lanceoladoelíptica, base aguda, ápice acuminado ou falcado, margem inteira, face adaxial plana esparsamente estrelado-furfurácea a glabra, face abaxial plana, densamente adpresso-estrelado-furfurácea, ferrugínea, 3 nervuras acródromas basais com as internas não unidas por membrana. Inflorescências em tirsóides não glomeriformes, terminais, $5-7 \mathrm{~cm}$ compr.; brácteas e profilos não involucrais $0,5-1 \mathrm{~mm}$ 


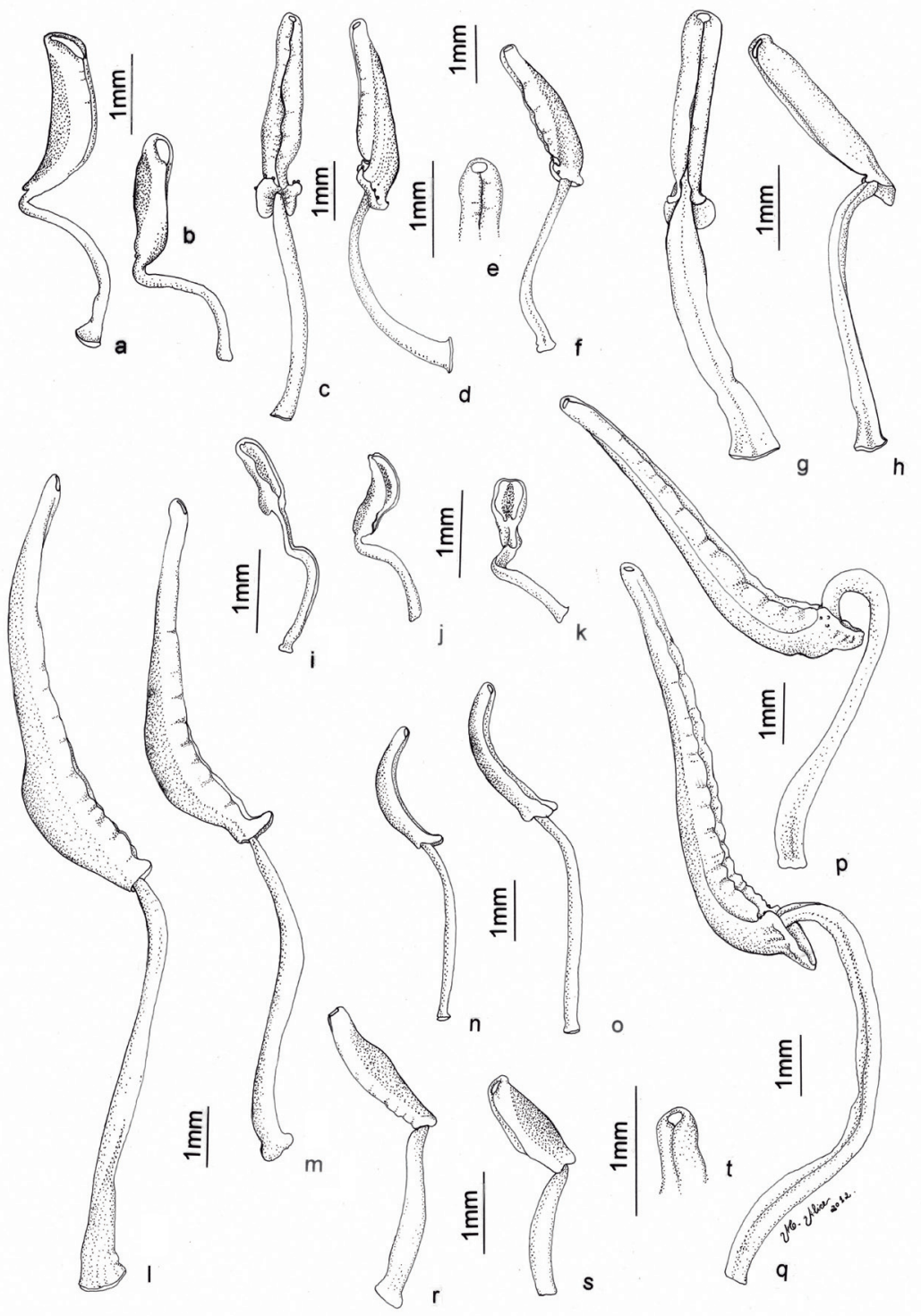

Figura 2: Espécies de Miconia do P.E. da Pedra Branca, Rio de Janeiro. a-b. Miconia brasiliensis. a-b. Estame antessépalo e antepétalo em vista lateral, respectivamente. c-f. Miconia calvescens. c-d. Estame antessépalo em vista frontal e em vista lateral, respectivamente.e. Detalhe do ápice da antera. f. Estame antepétalo em vista lateral. g-h. Miconia cinnamomifolia: g-h. estame antessépalo em vista frontal e lateral, respectivamente. i-j. Miconia mirabilis. i-j. Estame antessépalo e antepétalo em vista lateral, respectivamente. k-m. Miconia latecrenata. k. Detalhe da deiscência da antera em poro muito amplo, semelhante a uma rima. 1-m. Estame antessépalo e antepétalo em vista lateral, respectivamente. n-o. Miconia prasina. n-o. Estame antessépalo e antepétalo em vista lateral, respectivamente. p-q. Miconia staminea. p-q. Estame antessépalo e antepétalo em vista lateral, respectivamente. r-t. Miconia tristis. r-s. Estame antessépalo e antepétalo em vista lateral, respectivamente. t. Detalhe do ápice da antera. (a-b: M.F.O. Silva 124; c-f: M.F.O. Silva 82; g-h: J.F.A Baumgratz 800; i-k: L. Giordano 251; 1-m: L. Kollmann 10662; N-O: M.L. Marcon 4; p-q: Lima-Neto et al. 716; r-t: Vervoletet al. 2269).

Figure 2. Miconia species of P.E. da Pedra Branca, Rio de Janeiro. a-b. Miconia brasiliensis. a-b. Antesepalous and antepetalous stamens in lateral view, respectively. c-f. Miconia calvescens.c-d. Antesepalous stamen in frontal and lateral view, respectively. e. Detail of anther apex. f. Antepetalous stamen in lateral view. g-h. Miconia cinnamomifolia. g-h. Antesepalous stamen in frontal and lateral view, respectively. i-j. Miconia mirabilis. i-j. Antesepalous and antepetalous stamens in lateral view, respectively. k-m. Miconia latecrenata. k. Detail of anther dehiscence. 1-m. Antesepalous and antepetalous stamens in lateral view, respectively. n-o. Miconia prasina. n-o. Antesepalous and antepetalous stamens in lateral view, respectively. p-q. Miconia staminea. p-q. Antesepalous and antepetalous stamens in lateral view, respectively. r-t. Miconia tristis. r-s. Antesepalous and antepetalous stamens in lateral view, respectively. t. Detail of anther apex. (a-b: M.F.O. Silva 124; c-f: M.F.O. Silva 82; g-h: J.F.A Baumgratz 800; i-k: L. Giordano 251; 1-m: L. Kollmann 10662; n-o: M.L. Marcon 4; p-q: Lima- Neto et al. 716; r-t: Vervolet et al. 2269). 
triangulares, estrelado-furfuráceos. Flores 5-meras, hipanto ca. $2 \mathrm{~mm}$ compr., campanulado, densamente estrelado-furfuráceo; zona do disco glabra, lacínias do cálice externas $0,5 \mathrm{~mm}$ compr., triangulares internas inconspícuas; pétalas ca. 1,5 $\mathrm{mm}$ compr., brancas, oblongas, ápice arredondado, glandulosas. Estames 10, isomorfos, com filetes ca. $2 \mathrm{~mm}$ compr., glabros, anteras ca. 2,7 mm compr., oblongas com ápice truncado e poro diminuto, conectivos pouco prolongados, os antepétalos não apendiculados e os antessépalos com calcar dorsal curto. Ovário 3-4 locular, adnato ao hipanto na base, ápice esparsamente hirtelo-glanduloso. Baga nigrescente.

Material examinado: BRASIL. Rio DE JANEIRO: Rio de Janeiro, Parque Estadual da Pedra Branca, margem da represa do Camorim, 11-VIII-2006, fl., M.F.O. Silva 123 (R, RB), idem, fl., M.F.O. Silva 125 (R, RB); encosta acima da represa, 11-VIII-006, fl., M.F.O. Silva 126 (R, RB).

Ocorre apenas no Brasil, nos Estados do Espírito Santo, Rio de Janeiro, São Paulo e Santa Catarina (Goldenberg 2012a). As folhas lanceoladas com ápice longamente acuminado e coloração ferrugínea na face abaxial permitem prontamente o reconhecimento dessa espécie no PEPB.

No PEPB está restrita a poucas áreas, acima da vertente sobre a represa do Camorim, onde se distribui de maneira esparsa.

9. Miconia calvescens DC., Prodr. 3: 185.1828. Figura $2 \mathrm{c}-\mathrm{f}$

Árvore, 1,5-5 $\mathrm{m}$ alt. Indumento dos ramos, pecíolos e eixos da inflorescência com tricomas dendríticos estrelado-furfuráceos, depois caducos. Folhas com pecíolos 1,8-7 cm compr.; lâmina $8-37,4 \times 3,8-18,5 \mathrm{~cm}$, oval-elíptica, base obtusa a arredondada, às vezes subcordada, ápice agudoacuminado, margem crenulada a serrulada, ambas as faces planas, esparsamente recobertas por tricomas estrelado-furfuráceos, principalmente sobre as nervuras principais, depois caducos; 5 nervuras acródromas basais ou raramente as internas até $18 \mathrm{~mm}$ acima da base. Inflorescências em tirsóides de glomérulos terminais, $14-23 \mathrm{~cm}$ compr.; brácteas e profilos não involucrais 1,3-2 mm, obtusos, estreladofurfuráceos. Flores 5-meras, hipanto ca. $3 \mathrm{~mm}$ compr., campanulado, densamente estrelado-furfuráceo; zona do disco glabra; lacínias do cálice truncadas, sem lobos distintos; pétalas ca. 1,8 mm compr., brancas, oblongas, ápice arredondado, glabras ou esparsamente pilosas. Estames 10, subisomorfos com filetes ca. 3,5 mm compr., glabros, anteras ca. $3 \mathrm{~mm}$ compr., ápice atenuado, com poro terminal diminuto, conectivos pouco prolongados, dorsalmente espessados e ventralmente bilobados, glandulosos. Ovário 3-locular, ínfero, adnato ao hipanto na base, ápice glanduloso. Baga nigrescente, rósea ou vinosa.

Material examinado: BRASIL. Rio DE JANEIRO: Rio de Janeiro, Parque Estadual da Pedra Branca, Boiúna, 10-VI-2006, fl., M.F.O. Silva 81 (R, RB); morro da Mesa, 1-III-2003, fl., A. Solórzano et al. 29 (RB); caminho que leva ao Camorim, 25-VIII-1980, fr., M.C. Vianna et al. 1519 (GUA); estrada da Boiúna, 8-VII-1954, fl., E. Pereira 735 (RB).

Miconia calvescens distribui-se desde a América Central até o Paraguai (Goldenberg 2009a). No Brasil é amplamente distribuída em todas as regiões e na maioria dos Estados (Goldenberg 2009a, 2012a). Pode ser identificada no PEPB pela grande dimensão das folhas discolores, vinosas na face abaxial e pelas inflorescências glomeruliformes com odor adocicado.

No PEPB M. calvescens geralmente domina a paisagem em áreas mais perturbadas, mas também ocorre de maneira esparsa em áreas mais conservadas no interior da floresta.

10. Miconia cinnamomifolia (DC.) Naudin, Ann. Sci. Nat. Bot. ser. 3(16): 168. 1850.

Figura 2 g-h

Árvore ca. $12 \mathrm{~m}$ alt. Indumento dos ramos, pecíolos folhas e eixos da inflorescência estreladofurfuráceo, depois caduco. Folhas com pseudoestípulas interpeciolares, pecíolos 0,3-1,8 cm compr.; lâmina $5-16,8 \times 2,2-5,6 \mathrm{~cm}$ oval-elíptica, base atenuada ou decurrente, ápice acuminado, margem inteira, revoluta ou pouco crenulada, espessada, ambas as faces planas, com indumento cedo caduco, 3 nervuras acródromas basais. Inflorescências em tirsóides não glomeriformes terminais, $3-7 \mathrm{~cm}$ compr.; brácteas e profilos não involucrais $0,8-1,5 \mathrm{~mm}$, linear-lanceolados, esparsamente estrelado-furfuráceos. Flores 5-meras, hipanto ca. 1,6 mm compr., campanulado, esparsamente estrelado-furfuráceo, zona do disco glabra, lacínias do cálice, externas ca. 0,6 mm compr., arredondadas, internas inconspícuas; pétalas 1,6-2,2 mm compr. brancas, obovadas, ápice arredondado, glabras. Estames 10, subisomorfos, com filetes ca. $1,8 \mathrm{~mm}$ compr., glabros, anteras 1,8-2 mm compr., oblongas 
com ápice obtuso e poro terminal diminuto, conectivos pouco prolongados, os antessépalos dorsalmente bilobados, e os antepétalos dorsalmente calcarados e ventralmente biauriculados. Ovário 3-locular, adnato ao hipanto até o terço superior, glabro. Baga roxonigrescente.

Material examinado: BRASIL. Rio DE JANEIRO: Rio de Janeiro, Parque Estadual da Pedra Branca, trilha para a represa do Camorim, 11-VIII-2006; veg., M.F.O. Silva 119 (R).

Material adicional: BRASIL, RIO DE JANEIRO: Rio de janeiro, Maciço da Tijuca, serra da Carioca, bairro Botafogo, morro Mundo Novo, Campus da Universidade Santa Úrsula, 17-VI-2000, fl., J.M.A. Braga 6040 (RB).

Endêmica do Brasil pode ser encontrada na Bahia, em todos os Estados da região Sudeste, Paraná e Santa Catarina (Goldenberg 2012a). No PEPB é a única espécie de Melastomataceae que possui projeções interpeciolares na região dos nós. O espécime encontrado no PEPB apresenta as folhas apenas com nervuras acródromas basais, um padrão de nervação que ocorre na espécie, porém, mais raro que o de folhas com nervuras suprabasais (Romero 1993, Baumgratz et al. 2006). Informações sobre alterações nomenclaturais são discutidas em Wurdack (1960), Romero (1993) e Goldenberg (2009a).

Miconia cinnamomifolia é bem distribuída no PEPB em diferentes altitudes, mas sem formar densas populações. Por atingir a altura de 12 metros, M. cinnamomifolia faz parte do dossel.

11. Miconia latecrenata (DC.) Naudin, Ann. Sci. Nat. Bot. ser. 3(16): 239. 1850.

Figura $2 \mathrm{i}-\mathrm{k}$

Árvore, 2-4 m alt. Indumento dos ramos, pecíolos e eixos da inflorescência estrelado-furfuráceo, ferrugíneo com tricomas dendríticos. Folhas com pecíolos 0,5-1,8 cm compr.; lâmina 7,6-15 × 2-7,5 cm, elíptica ou lanceolado-elíptica, base agudo-atenuada, ápice agudo-acuminado, margem denticulada, ambas as faces planas, esparsamente estreladofurfuráceas a glabras, 3-5 nervuras acródromas basais. Inflorescências tirsóides não glomeriformes, terminais e laterais, $5-8 \mathrm{~cm}$ compr.; brácteas e profilos não vistos. Flores 5-meras, hipanto 1,4-1,6 mm compr., campanulado, estrelado-furfuráceo, zona do disco glabra; lacínias do cálice, externas inconspícuas, internas ca. 0,4 mm compr., triangulares; pétalas
1,5-1,6 mm compr., brancas, obovadas, ápice assimétrico, glabras. Estames 10, subisomorfos, com filetes 1,5-1,6 mm compr., glabros, anteras 1,3-1,4 mm compr., oblongas, ápice obtuso com poro ventral amplo, às vezes, semelhante a uma rima, conectivos prolongados, curtamente calcarados dorsalmente e curtamente biauriculados ventralmente. Ovário 3-locular, adnato ao hipanto na base, ápice pubérulo. Baga roxo-nigrescente.

Material examinado: BRASIL. Rio DE JANEIRO: Rio de Janeiro, Parque Estadual da Pedra Branca, morro do Pau-da-fome, 7-V-1980, fl., D.S. Souza 54 (GUA); morro do Pau-da-fome, 19-II-1980, fl., C.M.S. Lira 141 (GUA).

Endêmica do Brasil é encontrada em todos os Estados das regiões Sul e Sudeste, além dos Estados de Pernambuco e Bahia, na Região nordeste (Goldenberg 2012a). Miconia latecrenata é a única espécie de Miconia no PEPB pertencente à seção Hypoxanthus e pode ser reconhecida pela combinação dos caracteres: lâmina foliar com a face abaxial esparsamente recoberta por tricomas estrelado-furfuráceos e anteras com poro ventral amplo, semelhante a uma rima.

Não foi possível recoletar essa espécie no PEPB, e informações relacionadas ao tipo de ambiente ocupado e outras particularidades necessitariam de observações adicionais.

12. Miconia mirabilis (Aubl.) L.O. Willians, Fieldiana, Bot. 29: 574. 1963.

Figura $21-\mathrm{m}$

Árvore 5-15 m alt. Indumento dos ramos, pecíolos e eixos da inflorescência estrelado-furfuráceo. Folhas com pecíolos 0,8-2,2 cm compr.; lâmina 6,7-11,5 × 2,8-6,2 cm, oval-elíptica, base arredondada, obtusa às vezes aguda, ápice acuminado, margem inteira ou ondulada, face adaxial plana, glabrescente; face abaxial plana, densamente estrelado-furfurácea, ferrugínea, 5-7 nervuras acródromas basais. Inflorescências em tirsóides não glomeriformes, terminais, 7,2-11 cm compr.; brácteas e profilos involucrais 3-7 mm compr., oblongos, estreladofurfuráceos. Flores 5-meras, hipanto ca. $5 \mathrm{~mm}$ compr., tubuloso, glabrescente; zona do disco glabra, lacínias do cálice muito reduzidas, irregularmente lobadas, denticuladas; pétalas 6-7 $\mathrm{mm}$ compr., brancas, obovadas, ápice obtuso, glabras. Estames 10, isomorfos, com filetes 5-6 mm compr., glabros, anteras 7-8 mm compr., linear-subuladas com poro ventral 
ou apical, diminuto, conectivos não prolongados, dorsalmente espessados e ventralmente biauriculados. Ovário 3-locular, adnato ao hipanto na base, ápice seríceo-setoso. Baga roxo-nigrescente.

Material examinado: BRASIL. Rio DE JANEIRO: Rio de Janeiro, Parque Estadual da Pedra Branca, 19-II-1981, fl. fr., C. Lira et al. 406 (GUA).

Miconia mirabilis ocorre do México ao Brasil (Berry 2001). Em território brasileiro foi coletada nos Estados de Amapá, Pará, Roraima, Alagoas, Bahia, Ceará, Pernambuco, Espírito Santo e Rio de Janeiro. (Goldenberg 2012a). Miconia mirabilis é próxima a Miconia staminea (Desr.) DC., principalmente pelas flores relativamente grandes, quando comparadas às demais espécies de Miconia do PEPB. Entretanto, são perfeitamente distintas pelo cálice irregularmente lobado e denticulado na primeira e apenas lobado na segunda. Além disso, M. mirabilis possui todas as nervuras foliares basais, e indumento na face abaxial densamente estrelado-furfuráceo, enquanto que em M. staminea as nervuras são suprabasais e a face abaxial é esparsamente estrelado-furfurácea.

Não foi possível recoletar essa espécie no PEPB, e informações relacionadas ao tipo de ambiente ocupado e outras particularidades necessitariam de observações adicionais.

13. Miconia prasina (Sw.)DC., Prodr. 3: 188. 1828. Figura 2 n-o

Arbusto ou árvore 2-4 $\mathrm{m}$ alt. Indumento dos ramos, pecíolos e eixos da inflorescência estreladofurfuráceo com tricomas dendríticos, caducos. Folhas com pecíolos 0,6-2,8 cm compr.; lâmina $6,2-17,3 \times 3-8,2 \mathrm{~cm}$, elíptica, oval e às vezes obovada, base agudo-atenuada, ápice agudo, margem crenulada, face adaxial plana, glabra, face abaxial plana, esparsamente estrelado-furfurácea, principalmente sobre as nervuras, 5 nervuras acródromas suprabasais, com as internas até $1,8 \mathrm{~mm}$ acima da base. Inflorescências em tirsóides não glomeriformes terminais, 2,8-11 cm compr.; brácteas e profilos não involucrais, persistentes no fruto $0,6-1 \mathrm{~mm}$ compr. triangulares, estrelado-furfuráceos. Flores 5-meras, hipanto 2-3 mm compr., tubuloso, esparsamente estrelado-furfuráceo, zona do disco glabra; lacínias do cálice fundidas, triangulares; pétalas ca. 1,5 mm compr., brancas, obovadas, ápice obtuso, glandulosas. Estames 10, isomorfos, com filetes ca. $2 \mathrm{~mm}$ compr., glabros, anteras ca. 2,7 mm compr., oblongas, ápice obtuso com poro terminal diminuto, conectivos não prolongados, dorsalmente espessados e ventralmente biauriculados. Ovário 3-4 locular, adnato ao hipanto na base, ápice esparsamente hirtelo-glanduloso. Baga nigrescente ou vinosa.

Material examinado: BRASIL. Rio DE JANEIRO: Rio de Janeiro, Parque Estadual da Pedra Branca, estrada da Boiúna, 10-VI-2006, fr., M.F.O. Silva 83 (R, RB); Boiúna, atrás do Clube da Polícia Civil, 10-VI-2006, fl., M.F.O. Silva 84 (R, RB); floresta da Covanca, 30-IX-1959, fl., A.P. Duarte 5028 (RB); Pau-da-fome, 22-I-1959, fl., E. Pereira \& A.P. Duarte 4239 (RB).

Ocorre desde a América Central e Caribe até o Paraguai (Goldenberg 2009a). No Brasil encontra-se distribuída por praticamente todos os Estados, com exceção do Acre, Piauí, Rio Grande do Norte, Santa Catarina e Rio Grande do Sul (Goldenberg 2012a). Miconia prasina é reconhecida pelo porte arbóreo e inflorescências não glomeriformes terminais com numerosas flores brancas e diminutas, brácteas persistentes no fruto e pelas folhas com base agudoatenuada. Para maiores informações ver Goldenberg (2004, 2009a) e Baumgratz et al. (2006).

Essa espécie é bastante comum no PEPB, principalmente em áreas abertas nas encostas do Pau-da-fome, porém sem formar densas populações.

14. Miconia staminea (Desr.) DC., Prodr. 3: 187. 1828.

Figura 2 p-q

Arbusto, 0,5-1,5 $\mathrm{m}$ alt. Indumento dos ramos, pecíolos e eixos da inflorescência estreladofurfuráceo, com tricomas dendríticos, depois caduco. Folhas com pecíolos 1,8-3 cm compr.; lâmina 7,2-16,7 × 4,3-8,5 cm, oval elíptica ou ovada, base arredondada ou obtusa, ápice agudo, margem inteira, face adaxial plana e esparsamente estrelado-furfurácea, principalmente sobre a base, face abaxial plana e esparsamente estrelado-furfurácea, principalmente sobre as nervuras, 5 nervuras acródromas suprabasais, com as internas até 5-7 mm acima da base. Inflorescências em tirsóides não glomeriformes, terminais, 3,2-11,6 cm compr.; brácteas e profilos não involucrais $0,5-2 \mathrm{~mm}$ compr., triangular-lanceolados, estrelado-furfuráceos. Flores 5-meras, hipanto ca. $5 \mathrm{~mm}$ compr., campanulado, estrelado-furfuráceo, zona do disco glabra; lacínias do cálice, externas ca. 1,5 mm compr., triangulares, internas ca. $2 \mathrm{~mm}$ compr., obovadas; pétalas ca. $8 \mathrm{~mm}$ 
compr., brancas, obovadas, ápice obtuso, papilosas. Estames 10, isomorfos com filetes 5-6 mm compr., glabros, anteras 7,5-8,5 mm compr., linear-subuladas com poro ventral ou apical diminuto, conectivos não prolongados, dorsalmente espessados e ventralmente biauriculados. Ovário 3-locular, adnato ao hipanto na base, papiloso. Baga róseo-nigrescente.

Material examinado: BRASIL. Rio DE JANEIRo: Rio de Janeiro, Parque Estadual da Pedra Branca, Boiúna, atrás do Clube da Polícia Civil, 24-VI-2006, fr., M.F.O. Silva 103 (R, RB); estrada da Boiúna, 10-VI-2006, fl., M.F.O. Silva 85 (R, RB).

A distribuição geográfica de Miconia staminea ainda é incerta. Segundo Goldenberg (2012a) é endêmica do Brasil, sendo encontrada nos Estados do Pará, Mato Grosso, Mato Grosso do Sul e Rio de Janeiro. Já Baumgratz et al. (2006), afirmaram que essa espécie ocorre no Paraguai, além dos Estados brasileiros da Bahia, Mato Grosso, Santa Catarina e em toda a região Sudeste. No PEPB, aproxima-se de Miconia mirabilis (ver comentários sobre essa espécie). Miconia staminea é bastante próxima a Miconia jucunda (DC.) Triana, que não ocorre no PEPB, e da qual provavelmente não difere. Para maiores informações ver Goldenberg $(2004,2009)$ e Baumgratz et al. (2006).

Miconia staminea está bem distribuída no PEPB em diversas altitudes sem formar densas populações.

15. Miconia tristis Spring, Flora 20 (2), Beibl.: 76. 1837.

Figura $2 \mathrm{r}-\mathrm{t}$

Árvore, 3-4 m alt. Indumento dos ramos, pecíolos e eixos da inflorescência muito esparso e cedo caduco, aparentemente glabro. Folhas com pecíolos 3-6 mm compr.; lâmina 5-11,6 × 1,7-3,6 cm, lanceoladoelíptica, base agudo-atenuada, ápice agudo-acuminado, margem ondulada, ambas as faces planas, glabras, 3 nervuras acródromas basais. Inflorescências em tirsóides terminais e laterais, 2,8-5,6 cm compr.; brácteas e profilos não involucrais, $0,3-1,8 \mathrm{~mm}$ compr., triangular-lanceolados, glabros. Flores 5-meras, hipanto ca. 1,5 mm compr., campanulado, glabro, zona do disco glabra; lacínias inconspícuas; pétalas ca. 1,5 mm compr., brancas, obovadas, ápice obtuso, glabras. Estames 10, isomorfos, com filetes ca. $2 \mathrm{~mm}$ compr., glabros, anteras ca. 1,5 mm compr., oblongo-subuladas, ápice atenuado com poro terminal diminuto, conectivos prolongados, curtamente calcarados dorsalmente e biauriculados ventralmente.
Ovário 3-locular, adnato ao hipanto na base, glabro. Baga roxo-nigrescente.

Material examinado: BRASIL. Rio DE JANEIRO: Rio de Janeiro, Parque Estadual da Pedra Branca, Boiúna, atrás do Clube da Polícia Civil, 24-VI-2006, fr., M.F.O. Silva 101 (R, RB), idem, fr., M.F.O. Silva 102 (R, $\mathrm{RB})$; trilha para a represa do Camorim, 11-VIII-2006, fr., M.F.O. Silva 126 (R, RB); caminho para represa da CEDAE, 2-II-1991, fl, C.A.L. Oliveira et al. 383 (GUA).

Miconia tristis é endêmica do Brasil e ocorre nos Estados da Bahia, Espírito Santo, Minas Gerais, Rio de Janeiro e São Paulo (Goldenberg 2012). É facilmente reconhecível no PEPB pelo porte arbóreo, folhas glabras e inflorescências terminais e laterais, com diminutas flores brancas. Para informações adicionais ver Goldenberg (2009).

É bem distribuída por todo o Parque em diversas altitudes, podendo dominar a paisagem em áreas mais perturbadas.

16. Mouriri arborea Gardner in Hooker, Ic. Pl. t. 515. 1843.

Árvore, 1,7 m alt. Ramos, pecíolos e eixos da inflorescência completamente glabros. Folhas com pecíolos 0,8-1,2 cm compr.; lâmina 6,6-9,8 × 1,8-4,2 cm, oblongo-elíptica, base aguda, ápice acuminado, margem inteira, ambas as faces planas, glabras, nervação broquidódroma. Inflorescências em dicásios, metatríades ou díades, nas axilas das folhas, 6-8 mm compr.; brácteas e profilos não vistos. Flores 5-meras, hipanto 3-3,5 mm compr., campanulado, glabro, fechado no botão, zona do disco glabra; lacínias do cálice 1-1,5 mm, rompendo-se irregularmente; pétalas ca. $2 \mathrm{~cm}$ compr., brancas ou amarelas, obovadas, ápice emarginado, glabras. Estames 10, subisomorfos, com filetes 7-9 mm compr., glabros, anteras ca. $4 \mathrm{~mm}$ compr., oblongas com ápice truncado, conectivos espessados com glândula dorsal. Ovário 4-locular, adnato ao hipanto até o terço superior, glabro. Frutos não vistos.

Material examinado: BRASIL. Rio DE JANEIRO: Rio de Janeiro, Parque Estadual da Pedra Branca, bacia de São Gonçalo do Amarante, Pindobal, 17-XI-1993, fl., $R$. Ribeiro 2172 (GUA).

Endêmica do Brasil, ocorre nos Estados de Minas Gerais, Espírito Santo e Rio de Janeiro. (Goldenberg 2012b). No PEPB é a única espécie com nervação 
broquidódroma e conectivos dos estames com uma glândula dorsal. Apesar de alguns trabalhos com enfoque regional (Goldenberg 2009, Goldenberg \& Martins 2009), não existem informações recentes sobre o gênero Mouriri desde a sua revisão (Morley 1976). Essa espécie é pouco representada nos herbários com apenas seis espécimes registrados para o Estado do Rio de Janeiro, que se somam às cerca de 40 amostras registradas para o Brasil (speciesLink 2012).

Não foi possível recoletar essa espécie no PEPB, e informações relacionadas ao tipo de ambiente ocupado e outras particularidades necessitariam de observações adicionais.

17. Ossaea amygdaloides (DC.) Triana, Trans. Linn. Soc. London, 28(1): 147. 1871.

Arbusto, 0,2-1,5 $\mathrm{m}$ alt. Indumento dos ramos, pecíolos e eixos da inflorescência piloso e setoso, com tricomas simples e estrelado-furfuráceos. Folhas com pecíolos 0,8-2 cm compr.; lâmina 5-11,2 × 0,8-3,3 cm, lanceolado-elíptica, base aguda, às vezes levemente obtusa, ápice acuminado ou falcado, margem inteira ou inconspicuamente crenulada, ciliada, face adaxial plana, esparsamente híspido-setosa com tricomas simples, face abaxial plana, esparsa a moderadamente vilosa, setosa e setulosa, com tricomas simples sobre a lâmina e estrelado-furfuráceos sobre as nervuras, 5 nervuras acródromas suprabasais, com as internas até $3 \mathrm{~mm}$ acima da base. Inflorescências em dicásios, axilares, 4-6 cm compr.; brácteas e profilos não involucrais 1-1,5 mm compr., lanceolados, esparsamente estrelado-setulosos. Flores 5-meras, hipanto ca. $3 \mathrm{~mm}$ compr., campanulado, setoso, com tricomas simples e estrelado-furfuráceos, zona do disco com tricomas simples e estrelados; lacínias do cálice, externas ca. 3,5 mm compr., lanceoladas, internas 1,2 mm compr., triangulares; pétalas ca. $2 \mathrm{~mm}$ compr., brancas, lanceoladas, ápice agudo, glabras. Estames 10, isomorfos, com filetes ca. 1,3 mm compr., glabros, anteras ca. 1,7 mm compr., obovadas, conectivos não prolongados, inapendiculados. Ovário 3-locular, adnato ao hipanto na base, setoso. Baga roxo-nigrescente.

Material examinado: BRASIL. Rio de Janeiro: Rio DE JANEIRO, Parque Estadual da Pedra Branca, estrada da Boiúna, 10-VI-2006, fl., fr., M.F.O Silva 87 (RB); margem da represa do Camorim, 11-VII-2006, fr., M.F.O. Silva 115 (RB).
Ocorre no Paraguai e no Brasil em todos os Estados das regiões Sudeste e Sul do Brasil (Goldenberg et al. 2005, Souza \& Baumgratz 2012b). Os espécimes de Ossaea amygdaloides coletados no PEPB fogem um pouco de seu padrão morfológico mais comum que é o de folhas estreitamente lanceoladas (Souza 2009), algumas vezes aproximando-se do padrão observado em alguns indivíduos de O. marginata. Entretanto, Ossaea amygdaloides apresenta indumento persistente nos ramos e margens das lâminas foliares esparsamente ciliadas, enquanto em Ossaea marginata o indumento nos ramos é caduco e a margem da lâmina foliar é densamente recoberta por indumento setoso. Para maiores informações ver Goldenberg et al. (2005).

No PEPB habita margens de trilhas e clareiras, sendo frequentemente encontrada próxima a espécimes de Ossaea confertiflora e Ossaea marginata.

18. Ossaea confertiflora (DC.) Triana, Trans. Linn. Soc. London 28(1): 147. 1871.

Arbusto, 0,5-1,3 m alt. Indumento dos ramos, pecíolos e eixos da inflorescência viloso e setoso, com tricomas simples e estrelado-furfuráceos. Folhas com pecíolos 1,4-5 cm compr.; lâmina 5,8-13,4 × 2-6,8 cm, ovado-elíptica, base arredondada a obtusa, às vezes assimétrica, ápice acuminado, margem crenulada, ciliada, face adaxial plana, adpresso-setosa, com tricomas simples, face abaxial plana, densamente vilosa sobre a lâmina e setosa sobre as nervuras, com tricomas simples sobre a lâmina e estreladofurfuráceos sobre as nervuras, 5 nervuras acródromas suprabasais, com as internas até $7 \mathrm{~mm}$ acima da base. Inflorescências em dicásios, axilares, 4-6 cm compr.; brácteas e profilos não involucrais 1-1,8 mm compr., lanceolados, esparsamente estrelado-setulosos. Flores 5-meras, hipanto ca. $3 \mathrm{~mm}$ compr., campanulado, setoso, com tricomas simples e estrelado-furfuráceos, zona do disco com tricomas simples e estrelados; lacínias do cálice, externas ca. 3,5 mm compr., lanceoladas, internas $1 \mathrm{~mm}$ compr., triangulares; pétalas $2 \mathrm{~mm}$ compr., brancas, lanceoladas, ápice agudo, glabras. Estames 10, isomorfos, com filetes ca. 1,2 mm compr., glabros, anteras ca. 1,6 mm compr., oblongas, conectivos não prolongados e inapendiculados. Ovário 3-locular, adnato ao hipanto até o terço superior, ápice setoso. Baga roxonigrescente.

Material examinado: BRASIL. RIO DE JANEIRO: Rio de Janeiro, Parque Estadual da Pedra Branca, Camorim, entrada do Parque, 11-VIII-2006, fl., M.F.O. Silva 127 
(R, RB); trilha para a represa do Camorim, 7-X-2006, fl., M.F.O. Silva 133 (R, RB); estrada do Rio Grande, 24-X-1945, fl., L. Emgydio \& P. Dansereau 350 (R); Pedra Branca, 22-VIII-1932, fl., A.C. Brade 11972 (R); Pedra Branca, 8-X-1931, fl., fr., A.C. Brade 11179 (R).

Ocorre no Brasil nos Estados do Rio de Janeiro, São Paulo, Paraná e Santa Catarina (Goldenberg et al. 2005, Souza \& Baumgratz 2012b). No PEPB é a única espécie de Ossaea que apresenta lâmina foliar ovado-elíptica com a base obtusa, densamente recoberta por indumento viloso na face abaxial e margem nitidamente crenulada.

Ossaea confertiflora ocorre apenas nos locais mais úmidos e sombreados no PEPB.

19. Ossaea marginata (Desr.) Triana, Trans. Linn. Soc. London 28(1): 147. 1871.

Arbusto, 0,2-1,5 m alt. Indumento dos ramos, pecíolos e eixos da inflorescência setoso e setuloso com tricomas simples e estrelado-furfuráceos, depois caduco. Folhas com pecíolos 0,8-2,2 cm compr.; lâmina 5,4-10,8 × 2,2-5,2 cm, elíptica, base agudo-atenuada, às vezes obtusa, ápice acuminado, margem inconspicuamente crenulada, densamente adpresso-setosa, ciliada, face adaxial plana, esparsa a densamente adpresso-setosa, com tricomas simples, face abaxial plana, esparsa a moderadamente setulosa, com tricomas simples sobre a lâmina e estreladofurfuráceos sobre as nervuras, 5 nervuras acródromas suprabasais, com as internas até $3 \mathrm{~mm}$ acima da base. Inflorescências em dicásios, axilares, ca. $2 \mathrm{~cm}$ compr.; brácteas e profilos não involucrais $0,5-1,2 \mathrm{~mm}$ compr., lanceolados, esparsamente estrelado-setulosos. Flores 5-meras, hipanto ca. $3 \mathrm{~mm}$ compr., campanulado, setoso, com tricomas simples e estrelado-furfuráceos, zona do disco com tricomas simples e estrelados; lacínias do cálice, externas ca. $2 \mathrm{~mm}$ compr., lanceoladas, internas $0,5 \mathrm{~mm}$ compr., triangulares; pétalas ca. 1,5 $\mathrm{mm}$ compr., brancas, linear-subuladas, ápice agudo, glabras. Estames 10, isomorfos, com filetes ca. 1,7 mm compr., glabros, anteras ca. 2,2 mm compr., oblongas, conectivos não prolongados e inapendiculados. Ovário 3-locular, adnato ao hipanto até o terço superior, setoso. Baga roxo-nigrescente.

Material examinado: BRASIL. Rio DE JANEIRO: Rio de Janeiro, Parque Estadual da Pedra Branca, estrada da Boiúna, 10-VI-2006, fl., fr., M.F.O. Silva 94 (R, RB); Boiúna, atrás do Clube da Polícia Civil, 10-VI-2006, fl, fr., M.F.O. Silva 95 (R, RB); Boiúna, atrás do Clube da Polícia Civil, 24-VI-2006, fr., M.F.O. Silva 104
(R, RB); Camorim, 11-VIII-2006, fr., M.F.O. Silva 116 (R, RB); morro do Sacarrão, 7-XII-2002, fr., C.A.L. Oliveira \& Airton 2145 (GUA); vale do rio São Gonçalo, 15-IX-1994, fl., fr., J.P.P. Carauta et al. 6981 (GUA); morro do Pau-da-fome, 4-IX-1980, fl., fr., C.M.S. Lira et al. 240 (GUA); estrada da Covanca, 9-II-1968, veg., Z. Trinta et al. 1365 (GUA).

Ocorre na Argentina, Brasil e Paraguai (Goldenberg et al. 2005, Souza 2009). Em território brasileiro distribui-se pelos Estados do Mato Grosso do Sul, Minas Gerais, Espírito Santo, Rio de Janeiro, São Paulo, Paraná e Santa Catarina (Souza \& Baumgratz 2012b). É afim a Ossaea amygdaloides (ver comentários sobre essa espécie).

No PEPB Ossaea marginata ocorre em locais mais úmidos e sombreados.

20. Pleiochiton blepharodes (DC.) Reginato, R. Goldenb. \& Baumgratz, Rodr. 61(1): 116. 2010.

Arbusto ca. 0,5 m alt. Indumento dos ramos, pecíolos e eixos da inflorescência piloso e viloso com tricomas simples e esparsamente setoso-glandulares. Folhas com pecíolos $0,4-1 \mathrm{~cm}$ compr.; lâmina 4-7,5 × 2,3-4,6 cm, oval, base obtusa a arredondada, ápice agudo-acuminado, margem inteira, ciliada, face adaxial plana, moderadamente serícea, com tricomas simples, face abaxial plana, moderadamente vilosa e pilosa, com tricomas simples, 5 nervuras acródromas suprabasais, com as internas ca. 1,2 $\mathrm{mm}$ acima da base. Inflorescências cimóides axilares, ca. 2,6 cm compr.; brácteas e profilos involucrais 4-12 mm compr., ovados, setoso-ciliados. Flores 5-meras, hipanto 4,5-5 mm compr., campanulado, esparsamente setoso, com tricomas simples, zona do disco glabra; lacínias do cálice, externas ca. $4,5 \mathrm{~mm}$ compr., subuladas, internas $0,8-1,8 \mathrm{~mm}$ compr., triangulares; pétalas $0,8-1 \mathrm{~cm}$ compr., brancas, obovadas, ápice arredondado, glabras. Estames 10, isomorfos, com filetes 3-3,5 mm compr., glabros, anteras 3,5-4 mm compr., oblongas, conectivos não prolongados e inapendiculados. Ovário 3-locular, adnato ao hipanto na base, setoso e setoso-glanduloso. Baga roxonigrescente.

Material examinado: BRASIL. RIO DE JANEIRO: Rio de Janeiro, Parque Estadual da Pedra Branca, Camorim, 1931, fls., Freire et al. 132 (R).

É a espécie de Pleiochiton com maior amplitude de distribuição geográfica, habitando desde o Estado da Bahia até Santa Catarina (Reginato et al. 2010, 
Reginato 2012). É a única espécie de Melastomataceae no PEPB que apresenta inflorescências axilares com grandes brácteas involucrais (4-12 mm compr.).

Não foi possível recoletar essa espécie no PEPB, e informações relacionadas ao hábito epifítico e outras particularidades necessitariam de observações adicionais.

21. Rhynchanthera dichotoma (Desr.) DC., Prodr. 3: 107. 1828.

Arbusto, 0,5-1,5 $\mathrm{m}$ alt. Indumento dos ramos, pecíolos e eixos da inflorescência setuloso com tricomas simples e glandulares pedicelados. Folhas com pecíolos $0,3-1,2 \mathrm{~cm}$ compr., lâmina 0,8-6,4 × 0,2-3,8 cm, oblonga, base cordada, ápice agudo-acuminado, margem crenulada, ciliada, face adaxial plana, densamente adpresso-pilosa, face abaxial plana, moderadamente setulosa, 5-7(-9) nervuras acródromas basais. Inflorescências em dicásios, terminais e axilares ca. $6,6 \mathrm{~cm}$ compr.; brácteas e profilos não involucrais 2-3,5 mm compr., ovados, setulosos. Flores 5-meras, hipanto ca. $2 \mathrm{~mm}$ compr., tubuloso, setuloso, com tricomas simples e glandulares pedicelados, zona do disco glabra; lacínias do cálice uniseriadas 2,8-3 mm compr., triangulares; pétalas ca. $2 \mathrm{~cm}$ compr., roxas, obovadas, ápice assimétrico, ciliado-glandulosas. Estames 5, alternados com 5 estaminódios, isomorfos, com filetes 5,5-5,8 mm compr., glabros, anteras 4,5-5 mm compr., oblongas com ápice rostrado, conectivos prolongados e ventralmente calcarados. Ovário 5-locular, adnato ao hipanto na base, glabro. Cápsula castanha.

Material examinado: BRASIL. Rio DE JANEIRO: Rio de Janeiro, Parque Estadual da Pedra Branca, estrada do Camorim, 19-I-1939, fl., fr., B. Lutz 1226 (RB); Curicica, Jacarepaguá, 25-VII-1961, fl., fr., A. Duarte 5641 (RB).

Ocorre na Venezuela, Guianas, Peru e Brasil (Martins 2009). Em território brasileiro habita os Estados do Acre, Amazonas, Roraima, Goiás, Bahia, Minas Gerais, Espírito Santo, Rio de Janeiro, São Paulo e Santa Catarina (Martins \& Bernardo 2012). É a única espécie de Melastomataceae no PEPB que apresenta estaminódios alternados com estames, além de anteras com ápice rostrado.

Não foi possível recoletar essa espécie no PEPB, e informações relacionadas ao hábito epifítico e outras particularidades necessitariam de observações adicionais.
22. Tibouchina corymbosa (Raddi) Cogn. in Mart., Eichler \& Urban, Fl. bras. 14(3): 363. 1885.

Figura 3 a

Árvore ou arbusto 2-5 m alt. Indumento dos ramos, pecíolos e eixos da inflorescência estrigoso com tricomas simples. Folhas com pecíolos $0,5-2,2 \mathrm{~cm}$ compr.; lâmina 2,5-9 × 1,8-3,7 cm, lanceolado-ovada, base obtusa a truncada, ápice agudo-acuminado, margem inteira, ciliada, face adaxial plana, híspida, face abaxial plana, esparsa a moderadamente estrigoso-serícea sobre a lâmina e setosa sobre as nervuras, 5 nervuras acródromas basais, com as externas ca. $1 \mathrm{~mm}$ acima da base. Inflorescências em tirsóides terminais, 3-11,5 cm; brácteas e profilos não involucrais, 3-6 mm compr., lanceolado-agudos, seríceo-estrigosos. Flores 5-meras, hipanto ca. 5,7 mm compr., tubuloso, seríceo, zona do disco glabra, lacínias do cálice unilobadas, ca. 1,6 mm compr., triangulares; pétalas ca. $2 \mathrm{~cm}$ compr., roxas, obovadas, ápice emarginado e assimétrico, ciliadas. Estames 10, subisomorfos, com filetes antessépalos ca. $7 \mathrm{~mm}$ compr., antepétalos ca. $9 \mathrm{~mm}$ compr., com tricomas glandulares pedicelados no terço inferior, anteras antessépalas 6,5-7 mm compr., antepétalas 8-9 mm compr., linear-subuladas, conectivos prolongados e ventralmente bilobados. Ovário 5-locular, adnato ao hipanto na base, setoso. Cápsula castanha.

Material examinado: BRASIL. Rio DE JANEIRO: Rio de Janeiro, Parque Estadual da Pedra Branca, estrada da Boiúna, 4-XI-2006, fl., M.F.O. Silva 160 (R, RB); margem da represa do Camorim, 2-XII-2006, fl., fr., M.F.O. Silva 201 (R, RB).

Endêmica do Estado do Rio de Janeiro (Guimarães 2012). Pode ser diferenciada das demais espécies de Tibouchina no Parque pelo formato ligeiramente truncado da base da lâmina foliar, que apresenta as nervuras externas divergindo acima das internas.

Tibouchina corymbosa é bem distribuída por todo o Parque habitando em clareiras e afloramentos rochosos, mas só forma populações com grande número de indivíduos em áreas abertas.

23. Tibouchina estrellensis (Raddi) Cogn. in Mart., Eichler \& Urban, Fl. Bras., 14 (3): 342. 1885. Figura 3 b-d

Árvore 8-20 m alt. Indumento dos ramos, pecíolos e eixos da inflorescência adpresso-escabro, seríceo e estrigoso com tricomas dendríticos. Folhas com pecíolos 1-1,5 cm compr.; lâmina 7-17 × 3,4-5,5 cm, 

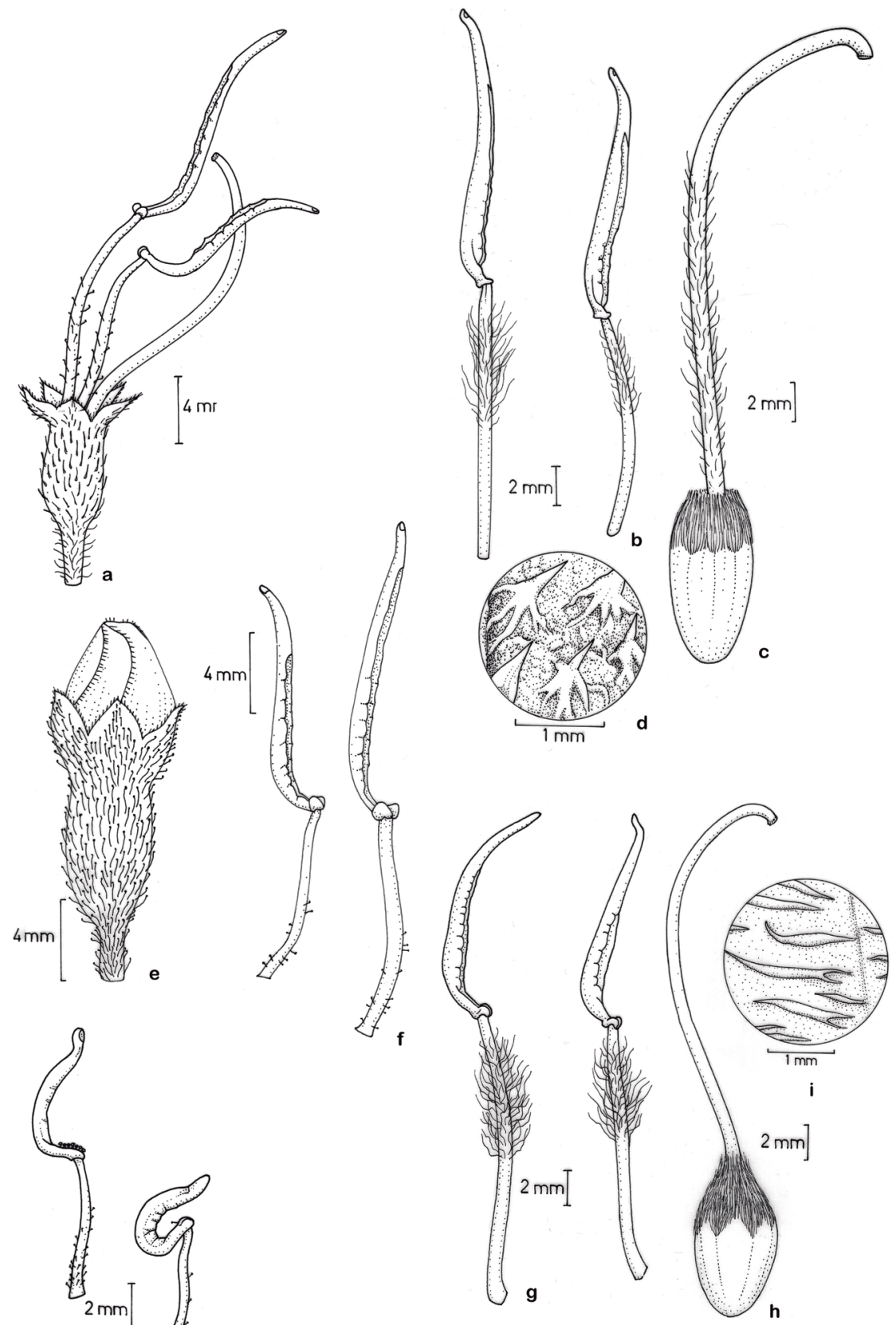

Figura 3. Espécies de Tibouchina do P.E. da Pedra Branca, Rio de Janeiro. a. Tibouchina corymbosa. a. Hipanto, estames e estilete. b-d. Tibouchina estrellensis. b. Estame antessépalo e antepétalo em vista lateral, respectivamente. c. Pilosidade do ápice do ovário e do estilete. d. Detalhe do indumento da face adaxial. e-f. Tibouchina gaudichaudiana. e. Botão floral. f. Estame antessépalo e antepétalo em vista lateral, respectivamente. g-i. Tibouchina granulosa. g. Estame antessépalo e antepétalo em vista lateral, respectivamente. h. Pilosidade do ápice do ovário e do estilete. i. Detalhe do indumento da face adaxial. j. Tibouchina heteromalla. j. Estame antessépalo e antepétalo em vista lateral, respectivamente. (a: P. Dusén 112; b-d: Glaziou 15.989; e-f: Widgren 986; g-i: C. H. B. Monteiro s.n (SP 224462); j: Frazão s.n. (RB 10.775).

Figure 3. Tibouchina species of P.E. da Pedra Branca, Rio de Janeiro. a. Tibouchina corymbosa. a. Hypanthium, stamensandstyle. b-d. Tibouchina estrellensis. b. Antesepalous and antepetalous stamens in lateral view, respectively. c. Indumentum on ovary apex and style. d. Detail of indumentum on adaxial leaf surface. e-f. Tibouchina gaudichaudiana. e. Floral buds. f. Antesepalous and antepetalous stamens in lateral view, respectively. g-i. Tibouchina granulosa. g. Antesepalous and antepetalous stamens in lateral view, respectively. h. Indumentum on ovary apex and style. i. Detail of indumentum covering abaxial leaf surface. j. Tibouchina heteromalla. j. Antesepalous and antepetalous stamen in lateral view, respectively. (a: P. Dusén 112; b-d: Glaziou 15.989; e-f: Widgren 986; g-i: C. H. B. Monteiro s.n. (SP 224462); j: Frazão s.n. (RB 10.775). 
lanceolado-ovada, base obtusa ou aguda, ápice agudo, margem inteira, ciliada, face adaxial bulada, adpressoescabra, tricomas com a base pluriramificada, face abaxial foveolada, piloso-dendrítica sobre a lâmina e estrigoso-dendrítica sobre as nervuras principais, 5 nervuras acródromas basais, com as externas 1-2 mm acima da base. Inflorescências em tirsóides terminais, ca. $15 \mathrm{~cm}$ compr.; brácteas e profilos não involucrais 5-15 mm compr., ovado-elípticos, seríceos. Flores 5-meras, hipanto ca. $1 \mathrm{~cm}$ compr., tubuloso, seríceo, com tricomas simples, zona do disco glabra; lacínias do cálice unilobadas ca. $6 \mathrm{~mm}$ compr., lanceoladas; pétalas 4,2-4,5 cm compr., roxas, obovadas, ápice assimétrico, ciliadas. Estames 10, dimorfos, com filetes antessépalos 1-1,2 cm compr., antepétalos 1-1,5 cm compr., vilosos no terço superior, anteras antessépalas 1-1,2 cm compr., antepétalas 1,5-1,7 mm compr., linear-subuladas, conectivos prolongados e ventralmente bilobados. Ovário 5-locular, adnato ao hipanto até o terço superior, seríceo. Cápsula castanha.

Material examinado: BRASIL. RIO DE JANEIRO: Rio de Janeiro, Parque Estadual da Pedra Branca, margem da represa do Camorim, 2-XII-2006, fl., fr., M.F.O. Silva 198 (R, RB).

Endêmica do Brasil ocorre em todos os Estados da região Sudeste (Guimarães 2012). Aproxima-se de Tibouchina granulosa pelo porte arbóreo e morfologia da flor, mas apresenta a face adaxial da lâmina foliar nitidamente bulada e revestida por tricomas adpressoescabros com a base pluriramificada, sendo que em T. granulosa a lâmina foliar é plana e os tricomas possuem base bi ou triramificada.

Tibouchina estrellensis ocorre nas encostas mais altas do Camorim, geralmente em áreas mais úmidas, próximas à represa. Com até 20 metros de altura, essa espécie é encontrada no interior da floresta ocupando o dossel.

24. Tibouchina gaudichaudiana (DC.) Baill., Hist. des Pl. 7: 7. 1879.

Figura 3 e-f

Arbusto ca. $1 \mathrm{~m}$ alt. Indumento dos ramos, pecíolos e eixos da inflorescência seríceo e estrigoso, com tricomas simples. Folhas com pecíolos $0,3-1 \mathrm{~cm}$ compr.; lâmina 3,2-9 × 1,8-3,7 cm ovado-elíptica, base obtusa a cordada, ápice agudo, margem inteira, ciliada, face adaxial plana, moderadamente adpresso-serícea, face abaxial plana, densamente tomentoso-serícea, 5(-7) nervuras acródromas basais. Inflorescências em tirsóides terminais, 5-19 cm compr.; brácteas e profilos não involucrais 3-6 mm compr., lanceoladoagudos, seríceos. Flores 5-meras, hipanto ca. $8 \mathrm{~mm}$ compr., tubuloso, seríceo-estrigoso, com tricomas simples, zona do disco glabra; lacínias do cálice unilobadas ca. $4 \mathrm{~mm}$ compr., triangulares; pétalas 1,5-1,7 cm compr., roxas, obovadas, ápice assimétrico. Estames 10, dimorfos, com filetes antessépalos 7-8 mm compr., antepétalos 10-11 mm compr., com tricomas glandulares pedicelados no terço inferior, anteras antessépalas 9-10 mm compr., antepétalas 11-12 mm compr., subuladas, conectivos prolongados e ventralmente bilobados. Ovário 5-locular, adnato ao hipanto até o terço superior, setoso, às vezes setosoglanduloso. Cápsula castanha.

Material examinado: BRASIL. RIo DE JANEIRO: Rio de Janeiro, Parque Estadual da Pedra Branca, estrada da Boiúna, próximo ao Lar de Frei Luiz, 10-VI-2006, fl., fr., M.F.O. Silva 91 (R, RB); Boiúna, atrás do Clube da Polícia Civil, 10-VI-2006, fl., fr., M.F.O. Silva 93 (R, RB); Pau-da-fome, 11-XII-1980, fl., M.B. Casari 371 (GUA); estrada do Camorim, 19-I-1939, fl., fr., B. Lutz 1228 (RB); estrada do Camorim, Km 10, 19-I-1939, fl., fr., Markgraf \& A.C. Brade 3769 (GUA).

Endêmica do Estado do Rio de Janeiro (Guimarães 2012). Tibouchina gaudichaudiana pode ser reconhecida pelas folhas planas com indumento adpressoseríceo na face adaxial. Os espécimes examinados mostraram variação na densidade do indumento e na forma da base, que vai de obtusa a cordada em um mesmo indivíduo.

Foi coletada no PEPB em áreas abertas e ensolaradas, como clareiras e margens de trilhas, nas altitudes menores.

25. Tibouchina granulosa (Desr.) Cogn. in Mart., Eichler \& Urban, Fl. Bras. 14(3): 332. 1885. Figura 3 g-i

Árvore 3-10 m alt. Indumento dos ramos, pecíolos e eixos da inflorescência adpresso-escabro, seríceo e estrigoso com tricomas simples. Folhas com pecíolos 1,5-2 cm compr.; lâmina 8,3-16,7 × 3,4-5,5 cm, lanceolado-elíptica, base agudo-atenuada, ápice agudo-acuminado, margem inteira, ciliada, face adaxial plana, adpresso-escabra, tricomas com a base bi ou triramificada, face abaxial plana, pilosodendrítica sobre a lâmina e estrigoso-dendrítica sobre as nervuras principais, 5 nervuras acródromas basais com as externas 1-2 mm acima da base. 
Inflorescências em tirsóides, terminais, ca. $17 \mathrm{~cm}$ compr.; brácteas e profilos não involucrais 2-14 mm compr., ovado-elípticos, seríceos. Flores 5-meras, hipanto 1-1,2 cm compr., tubuloso, seríceo, com tricomas simples, zona do disco glabra; lacínias do cálice unilobadas 5-6 mm compr., lanceoladas; pétalas 4,5-4,7 cm compr., roxas ou róseas obovadas, ápice assimétrico, ciliadas. Estames 10, dimorfos, com filetes antessépalos 1-1,2 cm compr., antepétalos 1-1,5 cm compr., vilosos no terço superior, anteras antessépalas 1-1,2 cm compr., antepétalas 1,5-1,7 cm compr., linear-subuladas, conectivos prolongados e ventralmente bilobados. Ovário 5-locular, adnato ao hipanto até o terço superior, seríceo. Cápsula castanha.

Material examinado: BRASIL. Rio DE JANEIRo: Rio de Janeiro, Parque Estadual da Pedra Branca, Pau-da-fome, estrada do Calheris, 20-II-1980, fl., fr., C.M.S. Lira 110 (GUA).

Endêmica do Estado do Rio de Janeiro (Guimarães 2012). É caracterizada pelo porte arbóreo, morfologia das flores e pelas folhas com face adaxial bulada e recoberta por tricomas adpresso-estrigosos com base bi ou triramificada. As relações com T. estrellensis foram discutidas nos comentários desta.

No PEPB foi coletada nas imediações do Pau da Fome, e devido ao seu porte atinge o dossel.

26. Tibouchina heteromalla (D.Don) Cogn. in Mart., Eichler \& Urban, Fl. Bras. 14(3): 336. 1885. Figura $3 \mathrm{j}$

Arbusto ca. 1,5 m alt. Indumento dos ramos, pecíolos e eixos da inflorescência estrigoso e estrigoso-seríceo com tricomas simples. Folhas com pecíolos 0,5-1,6 cm compr.; lâmina 9-12 × 6,5-8,4 cm, cordado-ovada, base cordada ápice apiculado, margem inteira, face adaxial bulada, estrigoso-serícea, face abaxial foveolada densamente vilosa sobre a lâmina e seríceo-estrigosa sobre as nervuras, 7-9 nervuras acródromas basais. Inflorescências em tirsóides terminais, ca. $21 \mathrm{~cm}$ compr.; brácteas e profilos não involucrais 7-12 mm compr., lanceolado-agudos, seríceos. Flores 5-meras, hipanto ca. $5 \mathrm{~mm}$ compr., tubuloso, seríceo, com tricomas simples, zona do disco glabra; lacínias do cálice unilobadas ca. $4 \mathrm{~mm}$ compr. lanceoladas; pétalas $1,5 \mathrm{~cm}$ compr., roxas, obovadas, ápice truncado a emarginado, ciliadas. Estames 10, dimorfos, com filetes antessépalos 6-7 mm compr., antepétalos 5-6 mm compr., com tricomas glandulares pedicelados no terço inferior, anteras antessépalas
7-8 mm compr., antepétalas 5,5-6,5 mm compr., subuladas, conectivos prolongados e ventralmente bilobados. Ovário 5-locular, adnato ao hipanto na base, ápice setoso-seríceo. Cápsula castanha.

Material examinado: BRASIL. RIo DE JANEIRO: Rio de Janeiro, Parque Estadual da Pedra Branca, núcleo Pau-da-fome, próximo ao tanque de decantação, 8-IV-2006, fl., fr., M.F.O. Silva s.n. (RB481884).

Endêmica do Brasil ocorre nos Estados da Paraíba, Pernambuco, Goiás, Minas Gerais, Espírito Santo, São Paulo e Rio de Janeiro (Guimarães 2012). É a única espécie de Tibouchina no PEPB que possui tricomas glandulares nos estames, além de folhas cordadas e buladas na face adaxial, densamente recobertas por indumento seríceo.

O exemplar de $T$. heteromalla foi coletado próximo à residência de um morador da área, mas como não se tem certeza sobre sua ocorrência de maneira espontânea no PEPB, a mesma foi tratada no trabalho.

\section{Agradecimentos}

À CAPES e ao CNPq, pelas bolsas de Mestrado e Apoio Técnico concedidas ao primeiro autor (REFLORA CNPq Proc. Número 563541/2010-5) e de produtividade ao segundo. Ao INEA/RJ, pela autorização de pesquisa concedida. Ao Diretor e aos funcionários do Parque Estadual da Pedra Branca, pelo auxílio durante as coletas. Aos editores e aos revisores anônimos, pelas críticas feitas ao manuscrito final; ao Dr. José Fernando de Andrade Baumgratz, pelas considerações durante a realização deste trabalho; ao Msc. Marcelo Reginato, por compartilhar informações sobre o gênero Leandra; à Dra. Tatiana Ungaretti Paleo Konno, pelo auxílio durante a realização deste trabalho no NUPEM/UFRJ. Aos curadores dos herbários visitados, pelo empréstimo de material. A ilustradora científica Maria Alice de Rezende, pela confecção das pranchas.

\section{Literatura citada}

APG - Angiosperm Phylogeny Group. 2009. An update of the Angiosperm Phylogeny Group classification for the orders and families of flowering plants: APG III. Botanical Journal of the Linnean Society 161: 105-121.

Barberena, F.F.V., Baumgratz, J.F.A. \& Chiavegatto, B. 2008. Melastomataceae no Parque Nacional do Itatiaia, Sudeste do Brasil: Tribos Bertolonieae e Merianieae. Rodriguésia 59: 381-392. 
Baumgratz, J.F.A. \& Souza, M.L.D.R. 2011. Melastomataceae na Reserva Ecológica de Macaé de Cima, Nova Friburgo, Rio de Janeiro, Brasil. II Leandra (Miconieae). Rodriguésia 62: 629-662.

Baumgratz, J.F.A., Souza, M.L.D.R. Carraça, D.C. \& Abbas, B.A. 2006. Melastomataceae na Reserva Biológica de Poço das Antas, Silva Jardim, RJ: Aspectos Florísticos e Taxonômicos. Rodriguésia 57: 591-646.

Baumgratz, J.F.A., Souza, M.L.D.R. \& Tavares, R.A.M. 2007. Melastomataceae na Reserva Ecológica de Macaé de Cima, Nova Friburgo, Rio de Janeiro, Brasil I - Tribos Bertolonieae, Merianieae e Microlicieae. Rodriguésia 58: 797-822.

Baumgratz, J.F.A., Bernardo, K.F.R., Chiavegatto, B., Goldenberg, R., Guimarães, P.J.F., Kriebel, R., Martins, A.B., Michelangeli, F.A., Reginato, M., Romero, R., Souza, M.L.D.R. \& Woodgyer, E. 2012. Melastomataceae. Lista de Espécies da Flora do Brasil. http://floradobrasil.jbrj.gov.br/2012/FB000161 (acesso em 30.07.2012).

Berry. 2001. Miconia. In: P.E. Berry, K. Yatskievych, \& B.K. Holst (eds.). Flora of the Venezuelan Guayana. Missouri Botanical Garden Press, St. Louis, pp. 387-468.

Chiavegatto, B. 2012. Meriania. Lista de Espécies da Flora do Brasil. http://floradobrasil.jbrj.gov.br/2012/ FB009655 (acesso em 01.07.2012).

Chiavegatto, B. \& Baumgratz, J.F.A. 2008. Meriania (Melastomataceae, Merianieae) no Rio de Janeiro, Brasil. Rodriguésia 59: 899-913.

Clausing, G. \& Renner, S.S. 2001. Molecular phylogenetics of Melastomataceae and Memecylaceae: implications for character evolution. American Journal of Botany 88: 486-498.

Cogniaux, A. 1886-1888. Melastomataceae. Tribus Miconieae. In: C.F.P Martius, A.G. Eichler \& I. Urban (eds.). Flora Brasiliensis. Typographia Regia, Monachii, v.14, pp. 66-558.

Conti, E., Litt, A. \& Sytsma, K.J. 1996. Circumscription of Myrtales and their relationships to other rosids: evidence from $\mathrm{rbcL}$ sequence data. American Journal of Botany 83: 221-233.

Corrêa, A.M. 1936. O Sertão Carioca. In: Revista do Instituto Histórico e Geográfico Brasileiro. Reimpressão. Departamento de Imprensa Oficial, Rio de Janeiro.

Costa, N.M. 2002. Análise do Parque Estadual da Pedra Branca por Geoprocessamento: uma contribuição ao seu plano diretor. Tese de Doutorado, Universidade Federal do Rio de Janeiro, Rio de Janeiro.

Firme, R.P., Vincenz, R.S., Macedo, G.V., Silva, I.M. \& Oliveira, R.R. 2001. Estrutura da Vegetação de um trecho de mata atlântica sobre solos rasos (Maciço da Pedra Branca, RJ.) Eugeniana 25: 3-10.
Fundação SOS Mata Atlântica/Instituto Nacional de Pesquisas Espaciais. 2002. Atlas dos Remanescentes Florestais da Mata Atlântica, Relatório Parcial. http:// www. sosmataatlantica.org.br (acesso em 15.03.2007).

Goldenberg, R. 2009a. Miconia. In: M.G.L. Wanderley, G.J. Shepherd, T.S. Melhem, A.M. Giulietti. \& S.E. Martins (eds.). Flora Fanerogâmica do Estado de São Paulo. FAPESP, São Paulo, v.6., pp. 73-103.

Goldenberg, R. 2009b. Mouriri. In: M.G.L. Wanderley, G.J. Shepherd, T.S. Melhem, A.M. Giulietti. \& S.E. Martins (eds.). Flora Fanerogâmica do Estado de São Paulo. FAPESP, São Paulo, v.6, pp. 108-110.

Goldenberg, R. 2012a. Miconia. Lista de Espécies da Flora do Brasil. http://floradobrasil.jbrj.gov.br/2012/ FB009675 (acesso em 30.06.2012).

Goldenberg, R. 2012b. Mouriri. Lista de Espécies da Flora do Brasil. http://floradobrasil.jbrj.gov.br/2012/ FB009815 (acesso em 30.06.2012).

Goldenberg, R. \& Martins A.B. 2009. Flora de GrãoMogol, Minas Gerais: Memecylaceae. Boletim de Botânica da Universidade de São Paulo 27: 97-98.

Goldenberg, R., Souza, C.M.F. \& Dequech, H.B. 2005. Clidemia, Ossaea e Pleiochiton (Melastomataceae) no Estado do Paraná, Brasil. Hoehnea 32: 453-466.

Goldenberg, R., Baumgratz, J.F.A. \& Souza, M.L.D.R. 2012. Taxonomia de Melastomataceae no Brasil: retrospectiva, perspectivas e chave de identificação para os gêneros. Rodriguésia 63: 145-161.

Guimarães, P.J.F. 2012. Tibouchina. Lista de Espécies da Flora do Brasil. http://floradobrasil.jbrj.gov.br/2012/ FB009899 (acesso em 01 07.2012).

Hickey, M. \& King, C. 2000. The Cambridge Illustrated Glossary of Botanical Terms. Cambridge University Press, Cambridge.

Martins, A.B. 2009. Rhynchanthera. In: M.G.L. Wanderley, G.J. Shepherd, T.S. Melhem, A.M. Giulietti. \& S.E. Martins (eds.). Flora fanerogâmica do Estado de São Paulo. FAPESP, São Paulo, v.6, pp. 120-124.

Martins, A.B. \& Bernardo, K.F.R. 2012. Rhynchanthera Lista de Espécies da Flora do Brasil. http://floradobrasil. jbrj.gov.br/2012/FB009863 (acesso em 01.07.2012).

Michelangeli, F.A. \& Reginato, M. 2012. Clidemia. Lista de Espécies da Flora do Brasil. http://floradobrasil.jbrj. gov.br/2012/FB009447 (acesso em 01.07.2012).

Morley, T., 1976. Memecyleae (Melastomataceae). Flora Neotropica Monographs 15: 1-295.

Oliveira, R.R. 2005. As marcas do homem na floresta. História ambiental de um trecho de Mata Atlântica. Pontifícia Universidade Católica do Rio de Janeiro, Rio de Janeiro.

Oliveira, R.R., Silva, E. \& Macedo, G.V. 2003. Biomasssa de raízes finas e serapilheira em floresta secundária no Maciço da Pedra Branca, RJ. Eugeniana 26: 25-35. 
Radford, A.E., Dickinson, W.C., Massey, J.R. \& Bell, C.R. 1974. Vascular Plant Systematics. Harper \& Row Publishers, New York.

Reginato, M. 2012. Pleiochiton. Lista de Espécies da Flora do Brasil. http://floradobrasil.jbrj.gov.br/2012/ FB117217 (acesso em 01.07.2012).

Reginato, M. \& Goldenberg, R. 2012. Taxonomic notes on Leandra (Melastomataceae: Miconieae). Hoehnea 39: 201-206.

Reginato, M., Michelangeli, F.A. \& Goldenberg, R. 2010. Phylogeny of Pleiochiton (Melastomataceae, Miconieae): total evidence. Botanical Journal of the Linnean Society 162: 423-434.

Romero, R. 1993. Florística da família Melastomataceae na planície litorânea de Picinguaba, município de Ubatuba, Parque Estadual da Serra do Mar, SP. Dissertação de Mestrado, Universidade Estadual Paulista, Rio Claro.

Secretaria de Estado de MeioAmbiente e Desenvolvimento Sustentável do Estado do Rio de Janeiro. 2001. Atlas das Unidades de Conservação da Natureza do Estado do Rio de Janeiro. Editora Metalivros, São Paulo.

Silva, K.C. 2011. Melastomataceae na Marambaia, Rio de Janeiro, Brasil: diversidade taxonômica e aspectos florísticos. Dissertação de Mestrado, Universidade Federal Rural do Rio de Janeiro, Rio de Janeiro.

Silva, K.C. \& Baumgratz, J.F.A. 2008. Henriettea e Henriettella (Melastomataceae, Miconieae) no estado do Rio de Janeiro, Brasil. Rodriguésia 59: 887-897.

Souza, M.L.D.R. 2009. Ossaea. In: M.G.L. Wanderley, G.J. Shepherd, T.S. Melhem, A.M. Giulietti. \& S.E. Martins (eds.). Flora Fanerogâmica do Estado de São Paulo. FAPESP, São Paulo, v.6, pp. 110-116.
Souza, M.L.D.R. \& Baumgratz, J.F.A. 2009. Leandra. In: M.G.L. Wanderley, G.J. Shepherd, T.S. Melhem, A.M. Giulietti. \& S.E. Martins (eds.). Flora Fanerogâmica do Estado de São Paulo. FAPESP, São Paulo, v.6, pp. 32-68.

Souza, M.L.D.R. \& Baumgratz, J.F.A. 2011. Melastomataceae na Reserva Ecológica de Macaé de Cima, Nova Friburgo, Rio de Janeiro, Brasil II - Leandra (Miconieae). Rodriguésia 62: 629-662.

Souza, M.L.D.R. \& Baumgratz, J.F.A. 2012a. Leandra. Lista de Espécies da Flora do Brasil. http://floradobrasil. jbrj.gov.br/2012/FB009525 (acesso em 01.06. 2012).

Souza, M.L.D.R. \& Baumgratz, J.F.A. 2012b. Ossaea. Lista de Espécies da Flora do Brasil. http://floradobrasil. jbrj.gov.br/2012/FB009829 (acesso em 01.06.2012).

SpeciesLink. 2012. Mouriri. Xiloteca Calvino Mainieri (BCTw), Herbário da Escola Superior de Agricultura Luiz de Queiroz (ESA), Herbário do Jardim Botânico Plantarum (HPL), Herbário do Estado "Maria Eneyda P. Kaufmann Fidalgo" - Coleção de Fanerógamas (SP), Herbário da Universidade Estadual de Campinas (UEC). http://www.splink.org.br (acesso em 12.07.2012).

Thiers, B. 2012. [continuously updated]. Index Herbariorum: A global directory of public herbaria and associated staff. New York Botanical Garden's Virtual Herbarium. http://sweetgum.nybg.org/ih/ (acesso em 05.07.2012).

Veloso, H.P., Filho, A.L.R.R. \& Lima, J.C.A. 1991 Classificação da vegetação brasileira adaptada a um sistema universal. Instituto Brasileiro de Geografia e Estatística, Rio de Janeiro.

Wurdack, J.J. 1960. Certamen Melastomataceis VI. Phytologia 7: 233-243.

Wurdack, J.J. 1962. Melastomataceae of Santa Catarina. Sellowia 14: 109-217. 